Article

\title{
Sustainability and Competitiveness in the Tourism Industry and Tourist Destinations: A Bibliometric Study
}

\author{
Luis Seguí-Amortegui ${ }^{1}$, José Antonio Clemente-Almendros ${ }^{1, *}$, Rubí Medina ${ }^{2}$ and \\ Melanie Grueso Gala ${ }^{3}$ (D) \\ 1 Faculty of Business and Communication, Universidad Internacional de la Rioja, 26006 Logroño, Spain; \\ luisalberto.segui@unir.net \\ 2 Department of Civil and Environmental Engineering, Universitat Politècnica de Catalunya, \\ 08034 Barcelona, Spain; rubi.alejandra.medina@upc.edu \\ 3 Faculty of Economics, Universitat de València, 46022 Valencia, Spain; melanie.grueso@uv.es \\ * Correspondence: joseantonio.clemente@unir.net
}

Received: 16 October 2019; Accepted: 8 November 2019; Published: 12 November 2019

\begin{abstract}
This article presents an analysis of the state of the art on the relationship between tourism, sustainability and competitiveness (TSC); moreover, the analysis also includes a focus on tourism destination (TSCD). To that end, information on the publications in these fields from recent years was sourced from the Web of Science database. In addition, the VOSviewer software program was used to enable a more in-depth bibliometric study, allowing the results to be clustered by authors, institutions, countries, and journals. The study carried out revealed that 808 articles have been published on aspects relating to TCS and 409 regarding TSCD. The results obtained underscore the greater scientific output on aspects related to sustainability than on aspects related to competitiveness and also that there has been a significant and exponential increase in both cases in recent years. These three fields of study (tourism, sustainability and competitiveness) are rarely combined in the literature, highlighting the lack of a comprehensive overview of this trinity. The evidence reported here suggest that the trend identified represents a future line of work for the coming years.
\end{abstract}

Keywords: tourism; sustainability; competitiveness; tourism cluster; tourism destination; bibliometric analysis; web of science

\section{Introduction}

The new challenges facing the tourism industry, as well as its specific characteristics and structure, are creating a need for more in-depth knowledge about the factors that affect and shape this industry [1,2] The importance of the tourism industry to the economy has been extensively demonstrated [3-7]. Thus, a richer understanding of the relevant competitive factors is becoming crucial for helping companies in this industry to create strategies that improve their competitiveness [8,9].

In the same vein, it is vital to gain a better understanding of the influence that the concept of sustainability may have on the tourism industry $[10,11]$. When it comes to defining the tourism company's strategy, the elements to take into account should include a sustainable environment in the tourism destination, the prosperity of local communities, the appropriate use of natural resources, and the impact on the population and the environment [12-15].

As a consequence, a growing body of literature has focused on the relationship between tourism and competitiveness on the one hand, and between tourism and sustainability, on the other. However, this dichotomy or separation could give rise to questions about the extent to which sustainability and competitiveness can coexist [16]; this is particularly critical in the tourism industry, given its 
abovementioned importance to the economy. Thus, the implementation of policies that are both sustainable and competitive is becoming a key topic; accordingly, it is essential to jointly analyse these two dimensions.

Going further, one of the pillars of sustainable tourism is that destinations should be aligned with the United Nations Environment Programme and the World Tourism Organization (UNWTO). There are many factors that justify the need for a far more in-depth and richer understanding of this component of the tourism industry, especially when it comes to talking about sustainability and competitiveness: Tourism destinations are amalgams of different factors [17] requiring comprehensive management approaches. Promoting tourism destinations may be a source of business opportunities [18]. For instance, although Europe is the number one tourism destination of all the continents, factors such as demographic change will affect future market trends [18], such as the growth of tourism destinations in Asia [19]. Similarly, new ways of tourism directly related to specific sites or destinations are enhanced, such as cultural urban tourism [20] and cultural heritage tourism [21].

Although the concept of sustainability may suffer from a clear definition [22,23], it seems clear that it includes the necessity of preserving limited resources for the future [24]. This demand is closely related to the definition of tourist destination as a combination of natural resources [25] or a mixture of products, services and experiences lived in a specific area [17]. Both concepts, sustainability and tourist destinations converge in the definition of sustainable tourism, which regards the environmental, together with social and economic consequences and handles the needs of tourists, companies, environment and tourist destinations [26]. In this manner, the competitiveness of tourism destinations should comprise the sustainability of the destination resources, together with the consideration of social and economic aspects [17]. As a consequence, and considering that a destination is based on the attributes it offers [27], sustainable firms' policies will lead to create value among tourism companies and its close context as well as an improvement in the performance of the company [16].

Accordingly, the aim of this paper is to carry out a bibliometric analysis on two different levels. First, the focus is on the complex concept of tourism, competitiveness and sustainability (TCS). Second, we incorporate the concept of a tourism destination or tourism cluster (TCSD), as this is an important element that has received scarce attention in the literature to date.

Notwithstanding the crucial importance of sustainability and competitiveness in the tourism industry, when taken together they are the subject of far few studies than when the two concepts are approached independently. By using the technique of bibliometrics, we aim to pinpoint TCS and TCSD studies in the literature. Bibliometrics is used to search and study specific academic fields and to draw detailed conclusions about research trends based on previous publications $[28,29]$.

This bibliometric study will be beneficial not only for researchers but also for decision-makers in public and private organizations. For researchers, it offers a visually appealing depiction of how this topic has been approached thus far and sheds some light on potential future trends. For decision makers, it will help them to make decisions tailored to achieving their goals, in a form of management that combines sustainability and competitiveness. We first focus on TCS, taking the total number of 808 publications, and then on TCSD, with 409 publications. We extract all these documents from the Web of Science (WoS) database and use VOSviewer software to visualize the bibliometric networks constructed on the basis of citation, co-citation, co-authorship and co-occurrence, among other elements.

The results reveal a lack of knowledge on how to implement sustainability policies that simultaneously allow the tourism firm to develop its competitiveness policies. There is a need for a multidisciplinary approach that brings together, on the one hand, environmental policies, good use of resources, etc., and on the other, the classic areas of business management, such as strategy, marketing, new technologies, etc. Lastly, effective coordination is needed between researchers, practitioners, and the government.

The rest of the paper is structured as follows: The next section describes the methodology and the data. Subsequently, the bibliometric analysis is described and visualized in Section 3. Finally, Section 4 contains the discussion and conclusions. 


\section{Methodology and Data}

WoS, owned by Thomson \& Reuters, is one of the most commonly-used databases in bibliometric studies, tracking scientific output in a way that provides more consistent, standardized data [28]. It is widely accepted that WoS provides the highest quality, most extensive output for academic and scientific studies [30]. Keyword studies are a good approach to identify and track scientific progress [31,32].

The data retrieval was performed on 31 July 2019, in order to retrieve the maximum numbers of publications and ensure the most up-to-date study possible. Hereafter, when we refer to 2019, we are referring to the part of the year up to this date.

Initially, in order to gain a more general overview of the publications, we conducted two searches. The first search was on the terms "tourism" AND ("sustainability" OR "sustainable"), yielding 10,651 results. The second was on the terms "tourism" AND ("competitiveness" OR "competitive"), yielding 3392 articles. Thus, we obtained what we call level TS and level TC respectively.

In line with the key aim of our study, we then added those terms together, creating the sample of TCS $(\mathrm{T}+\mathrm{C}+\mathrm{S})$, obtaining 808 articles; and going further, we created the sample TCSD (adding the term "destination" OR "cluster"), obtaining 409 articles. Cluster was added due to fact that it can be assimilated to the destination. The cluster is included in the Tourism Destination's definition [33]. The final sample retrieved was composed of 808 publications for TCS and 409 for TCSD.

In order to perform our analysis, we use the most widely-accepted measures in bibliometric research $[24,34,35]$ : total number of papers and citations, the h-index, the number of publications above a specific threshold, the impact factor, and the ratio of article citations per year (CY).

The analysis of the networks can be used to create a graphic map of the relationships between the data [32]. We use VOSviewer software [36] to visualize the bibliometric analysis of the publications. The technique is based on the use of nodes and lines (links). Nodes can represent authors, journals, countries, institutions, references, and keywords. Links between nodes can show citations, co-citations, collaboration, and co-occurrence. The analysis of clusters may show networks, helping to reveal groups and trends [37]. We thus display keyword co-occurrence; co-citation of cited references; journal co-citation; author co-citation; bibliographic coupling of authors; and co-authorship links between researchers, countries, or institutions.

VOSviewer software offers different graphic ways of conveying information. It uses a node to represent the number of papers in which a keyword is used, such that the bigger the node, the greater the weight of the keyword. Each node represents an item (author, paper or journal). The same colour represents a group of connected keywords or cluster. The connections or lines depict the number of articles in which a specific keyword appears in conjunction with another. Thicker lines indicate more regular co-occurrence; in other words, the intensity of cooperation. The distance between nodes reflects how many articles the two keywords are in together compared to co-occurrence with other keywords.

\section{Results}

First, this paper analyses the current situation and the evolution of tourism research as it relates to sustainability (TS) and also to competitiveness (TC). The analysis includes information on the number of publications per year, the number of citations per field and per document, the countries with the most publications, the journals (sources) with the greatest scientific output, and the authors who are most representative of the area.

Second, the paper analyzes the current situation and the evolution of tourism research related to sustainability and competitiveness (TCS), and as an additional element focuses on the TCS research related to tourism clusters or destinations (TCSD). In addition, it analyses the citation structure of the publications. Third, this study focuses on the most-cited articles on TCS and TCSD. The fourth part analyzes the most representative journals in these subjects. The fifth examines author keyword co-occurrence in TCS and TCSD. Sixth, the article explores the co-citation of references, journals and authors in the areas of TCS and TCSD. The seventh part investigates the bibliographic coupling 
between authors. Finally, the paper considers the networks of co-authorship linking countries and research institutions in the areas of TCS and TCSD.

\subsection{Trends in Tourism Research Related to Sustainability (TS) and Related to Competitiveness (TC)}

The first two articles on TS, [38,39], appear in WoS in 1990; since then, publications on the subject have been continuously generated (Figure 1). From 2002 onwards, more than 100 articles were published per year, with the exception of 2003 and 2004, in which there were 93 and 94 articles, respectively. And from 2015 on, more than 1000 articles were published per year, with as many as 1446 publications in 2018. Although fewer publications are observed for 2019 (due to the fact that the data search and retrieval was carried out on 31/07/2019), when analyzing the rate of publications per month, this rate is higher in 2019 (145.28 = 1017/7) than in 2018 (120.5 = 1446/12).

In the case of research on TC, the first article [38] appears in 1990 (Figure 1). From 2000 onwards, more than 10 articles were published per year. And from 2008 on, more than 100 articles were published per year, with as many as 458 publications in 2018. Analyzing the rate of publications per month, it can be seen that it is higher in $2019(40.28=282 / 7)$ than in $2018(38.16=458 / 12)$.

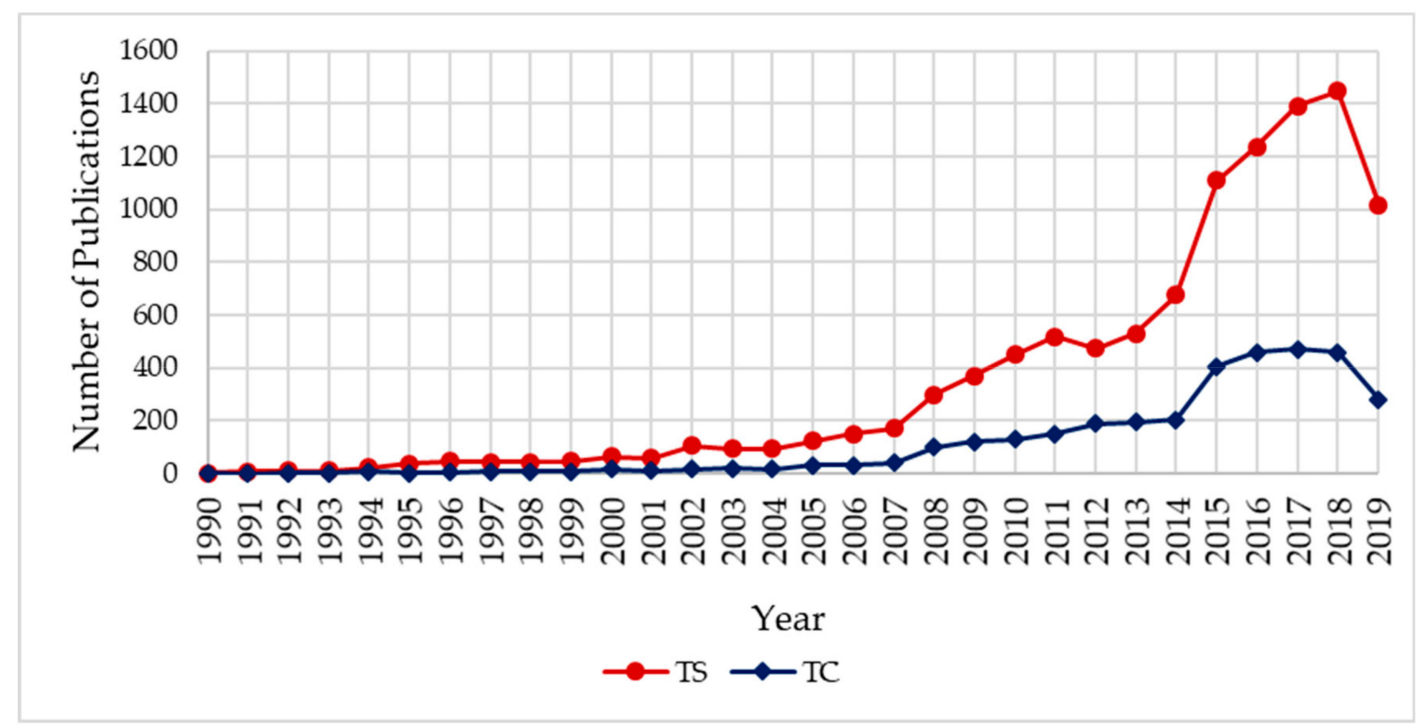

Figure 1. Annual publications in Web of Science (WoS) on TS and TC research. Source: own elaboration based on data from WoS 2019. The red line shows the number of publications per year in WoS on TS research; the blue line indicates the annual TC research.

Regarding citations on TS, the 10,651 published articles have registered a total of 88,667 citations. Looking at Figure 2, only $1.28 \%$ of the articles (136) have had more than 100 citations; $17.64 \%$ of the articles (1879) have had between 10 and 99 citations; $37.61 \%$ of the articles (4006) have had fewer than 10 citations; and $43.47 \%$ of the articles (4630) have had no citations at all. The three articles with the highest number of citations are Buhalis (2000) [17] with 994 citations, Gössling (2002) [40] with 361 citations and Choi and Sirakaya (2006) [41] with 346 citations. On the other hand, in the case of TC, the 3392 published articles have registered a total of 30,133 citations. Only $1.68 \%$ of the articles (57) have had more than 100 citations; $14.95 \%$ of the articles (507) have had between 10 and 99 citations; $34.14 \%$ of the articles (1158) have had fewer than 10 citations; and 49.23\% of the articles (1670) have had no citations at all (Figure 2). The three articles with the highest number of citations are Buhalis (2000) [17] with 994 citations, Crouch and Ritchie (1999) [42] with 583 citations and Gallarza and Saura (2006) [43] with 470 citations. If we compare the average number of citations per article in TS and TC research, we see similar figures: In the case of TS, it is 8.32 , and in the case of TC, it is 8.88 . 


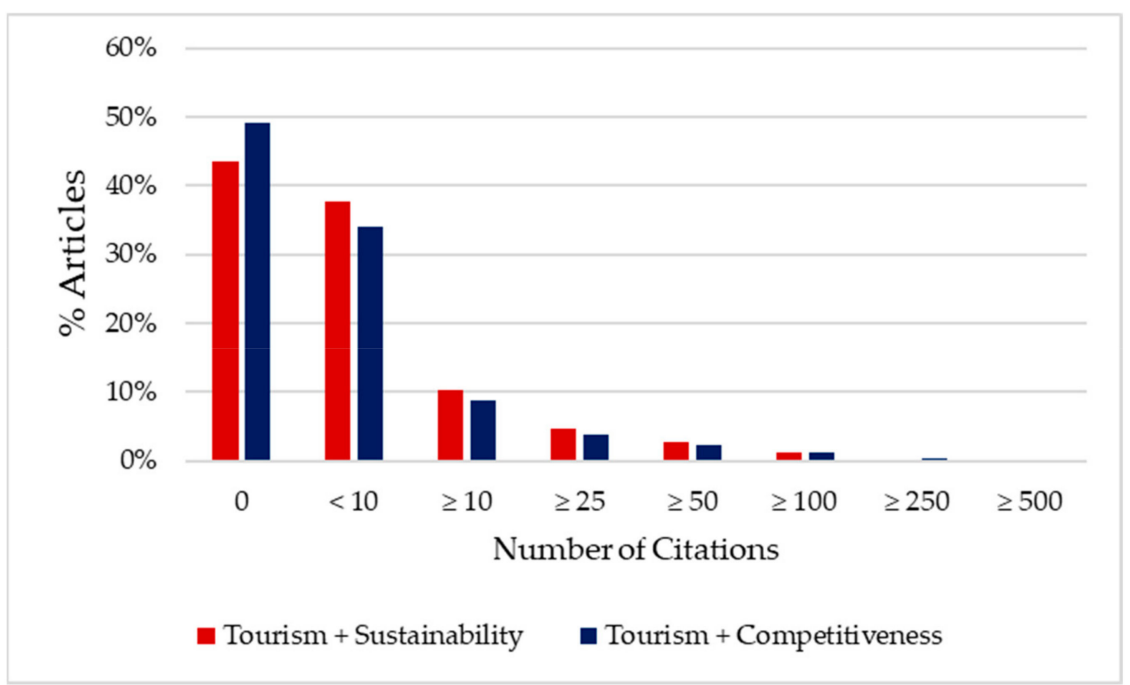

Figure 2. Citations on TS and TC. Source: own elaboration based on data from WoS 2019. The red bars show the percentage of publications on TS research with $0,<10, \geq 10, \geq 25, \geq 50, \geq 100, \geq 250$ and $\geq 100$ citations in WoS; the blue bars indicate the equivalent percentages for publications on TC research.

As shown in Figure 3, the countries with the most publications on TS are China with 1534 publications, the United States with 1084 publications, and Australia with 875 publications, representing $14.40 \%, 10.17 \%$ and $8.21 \%$ of all TS publications, respectively. In addition, 165 countries have contributed to the creation of 10,651 publications. Regarding TC research, the countries with the most publications are China with 429, Spain with 400, and the United States with 244, representing $12.64 \%, 11.79 \%$ and $7.19 \%$ of the total publications in this field (Figure 3), respectively. In addition, 117 countries have contributed to the creation of 3392 publications.

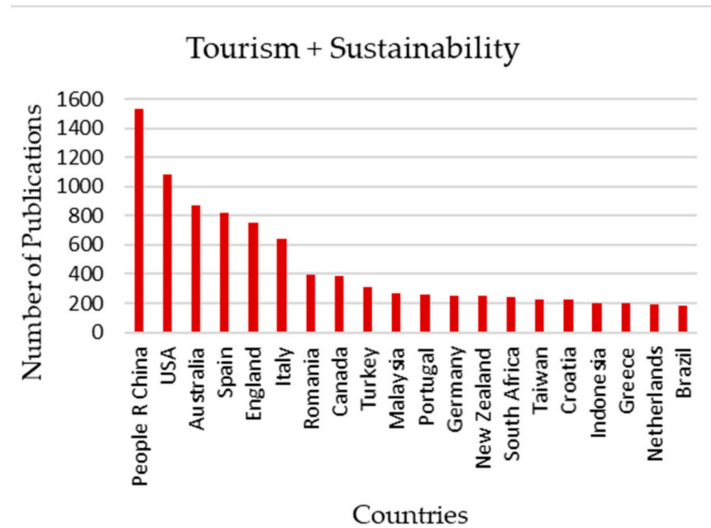

(a)

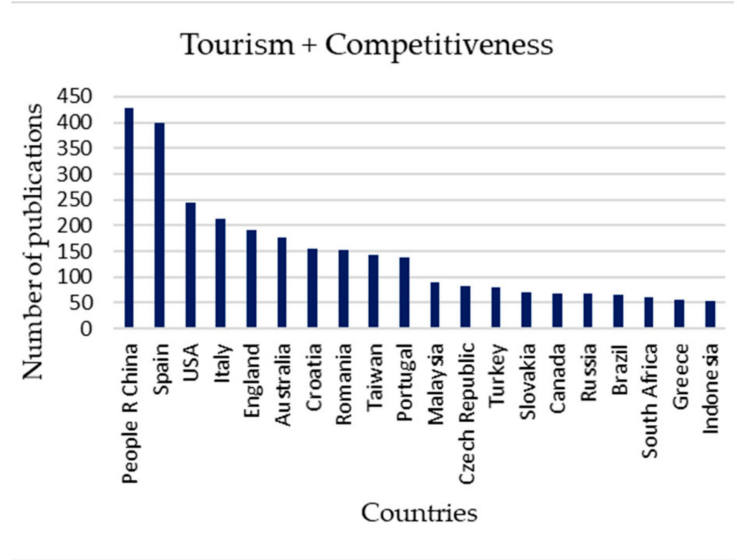

(b)

Figure 3. Total publications in Web of Science (WoS) on TS and TC, by country. Source: own elaboration based on data from WoS 2019. (a) The red bars in the first graph show the number of publications on TS research per country; (b) the blue bars indicate the number of publications on TC research per country.

According to Figure 4, the journals with the greatest scientific output on the topic of TS are Journal of Sustainable Tourism (Impact Factor: 3.4) with 617 publications, Sustainability (Impact Factor: 2.592) with 468 publications, and Tourism Management (Impact Factor: 6.012) with 335 publications, representing $5.79 \%, 4.39 \%$ and $3.15 \%$ of the total publications in this field, respectively. The journals with most publications on TC include Tourism Management (Impact Factor: 6.012) with a total of 149 publications, Tourism Economics (Impact Factor: 1.098) with 72 publications, and Current Issues in 
Tourism (Impact Factor: 3.395) with 66 publications, representing $4.39 \%, 2.12 \%$ and $1.95 \%$ of the total publications in this field, respectively (Figure 4).

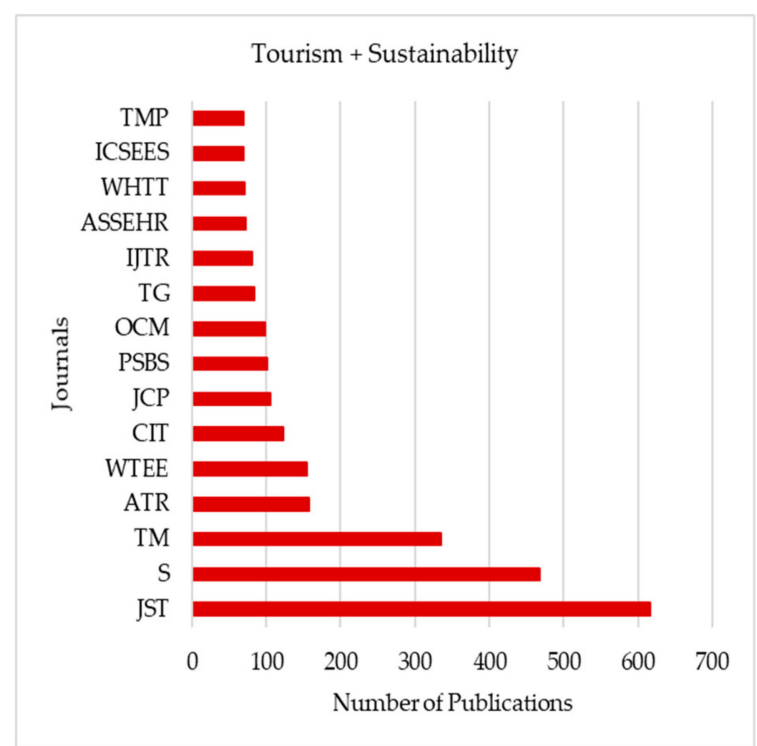

(a)

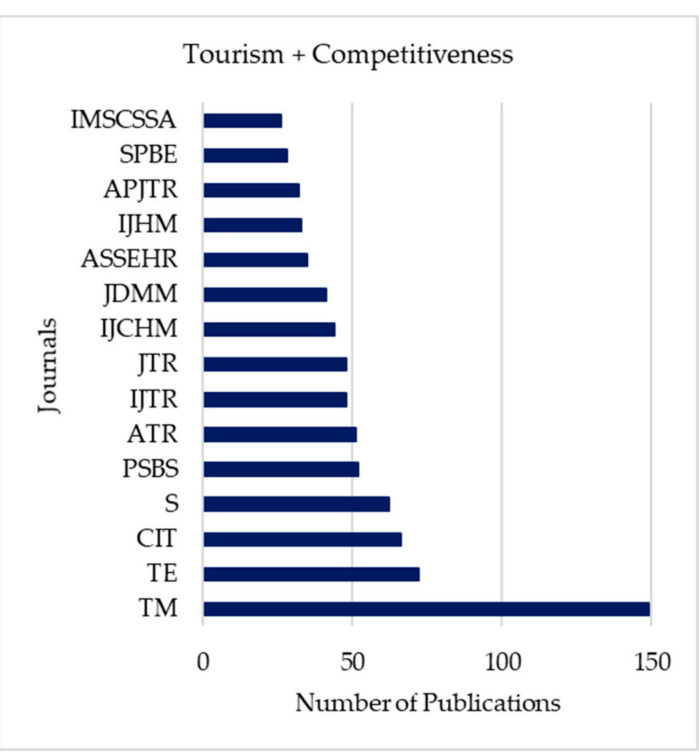

(b)

Figure 4. Publications in Web of Science (WoS) about TS and TC, by journal or source. Source: own elaboration based on data from WoS 2019. (a) The red bars in the first graph show the number of publications on TS research per journal; (b) the blue bars in the second graph indicate the number of publications on TC research per journal. ASSEHR: Advances in Social Science Education and Humanities Research; ATR: Annals of Tourism Research; APJTR: Asia Pacific Journal of Tourism Research; CIT: Current Issues in Tourism; IJCHM: International Journal of Contemporary Hospitality Management; IJHM: International Journal of Hospitality Management; IJTR: International Journal of Tourism Research; IMSCSSA: International Multidisciplinary Scientific Conferences on Social Sciences and Arts; ICSEES: IOP Conference Series Earth and Environmental Science; JCP: Journal of Cleaner Production; JDMM: Journal Of Destination Marketing Management; JST: Journal Of Sustainable Tourism; JTR: Journal of Travel Research; OCM: Ocean Coastal Management; PSBS: Procedia Social and Behavioral Sciences; SPBE: Springer Proceedings in Business and Economics; S: Sustainability; TE: Tourism Economics; TG: Tourism Geographies; TM: Tourism Management; TMP: Tourism Management Perspectives; WTEE: WIT Transactions on Ecology and the Environment; WHTT: Worldwide Hospitality and Tourism Themes.

As shown in Figure 5, the authors with the most publications on TS are Hall, C.M. with 53 publications (total articles generated: 158; h-index: 31), Gössling, S. with 42 publications (total articles generated: 161; h-index: 35), and Font, X. with 35 publications (total articles generated: 65; h-index: 20), representing $0.50 \%, 0.39 \%$ and $0.33 \%$ of the 10,651 publications in this field, respectively.

The authors with most publications on TC are Buhalis, D. with 18 publications (total articles generated by the author: 101; h-index: 30); Dwyer, L. with 14 publications (total articles generated by the author: 97; h-index: 20); and Pulido-Fernandez, J.I. with 12 publications (total articles generated by the author: 41 articles; h-index: 8), representing $4.39 \%, 2.12 \%$ and $1.95 \%$ of the 3392 publications on $\mathrm{TC}$, respectively. 


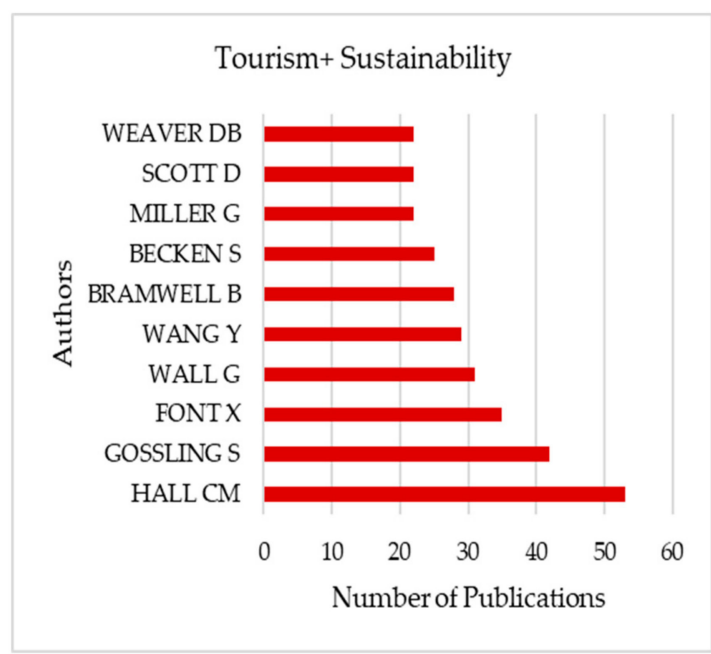

(a)

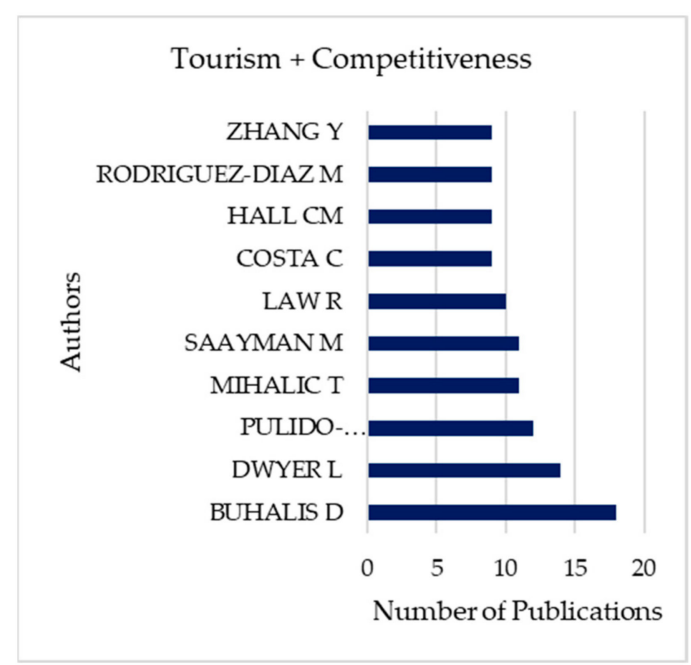

(b)

Figure 5. Publications in Web of Science (WoS) on TS and TC, by author. Source: own elaboration based on data from WoS 2019. (a) The red bars in the first graph show the number of publications on TS research per author; (b) the blue bars in the second graph indicate the number of publications on TC research per author.

\subsection{Trends in Tourism Research Related to Sustainability and Competitiveness (TCS) and TCS Related to Cluster/Tourism Destination (TCSD)}

Figure 6 highlights two important issues when we compare TCS with the publications related to Tourism and Sustainability (TS) or Tourism and Competitiveness (TC). The first is that the trend in publications related to TCS started later, just before 2007; and the second is that the level of annual publications is lower compared to the two previous concepts (TC y TS), going from 20 publications in 2010 to 120 in 2018 [29]. We could interpret these differences as reflecting the emerging concern about sustainable and competitive policies and issues in the tourism industry.

The first article related to TCS [38] appears in WoS in 1990; after that year, articles appeared intermittently (not every year saw an article published). However, from 1999 onwards, articles are published every year, starting with a single article in 1999 and reaching a total of 120 in 2018 (Figure 6). Analyzing the rate of publications per month, this rate is higher in $2019(12.42=87 / 7)$ than in 2018 $(10=120 / 12)$. A growing interest in research on the subject can be observed; although the search on TCS generated only 808 results, if we determine the increase over the last 10 years (2009 to 2018), we can see that TCS has increased by more than $300 \%$, a greater increase than the other topics analyzed (TS: $290 \%$, TC: $278 \%$ ).

The first article related to TCSD [44] appeared in WoS in 1994; after that year, articles appeared intermittently (not every year saw an article published). However, from 2008 onwards, articles have been published every year, starting with 7 articles in 2008 and reaching a total of 63 in 2018 (Figure 6). Analyzing the rate of publications per month, this rate is higher in $2019(8.14=57 / 7)$ than in 2018 $(5.25=63 / 12)$. A growing interest in research on the subject can be observed; although the search on TCSD generated only 409 results, if we determine the increase over the last 10 years (2009 to 2018), we can see that TCSD has increased by more than 380\%, a greater increase than the other topics analyzed (TS: $290 \%$, TC: $278 \%$, TCS: 300\%).

The influence of articles can be shown by using the number of citations as a measure of their relevance. Table 1 displays the citation level of all the papers published on TCS and TCSD at the date of the retrieval. When we focus on TCS, only one article received more than 500 citations; that is, $0.1 \%$ of the total. Analyzing all the articles, only $15.8 \%$ received more than 10 citations. This number is quite low when compared to other areas such as business, economics, physics, and chemistry [34]. 
Regarding citations of TCSD articles, it can be observed that only $3.67 \%$ (15) of the total articles (409) have more than 50 citations, 3.42\% (14) of the articles have between 25 and 49 citations, 9.54\% (39) have between 10 and 24 citations, and 83.37\% (341) have fewer than 10 citations. As for their h-index, for TCSD articles it is 28 (i.e., 28 articles have at least 28 citations).

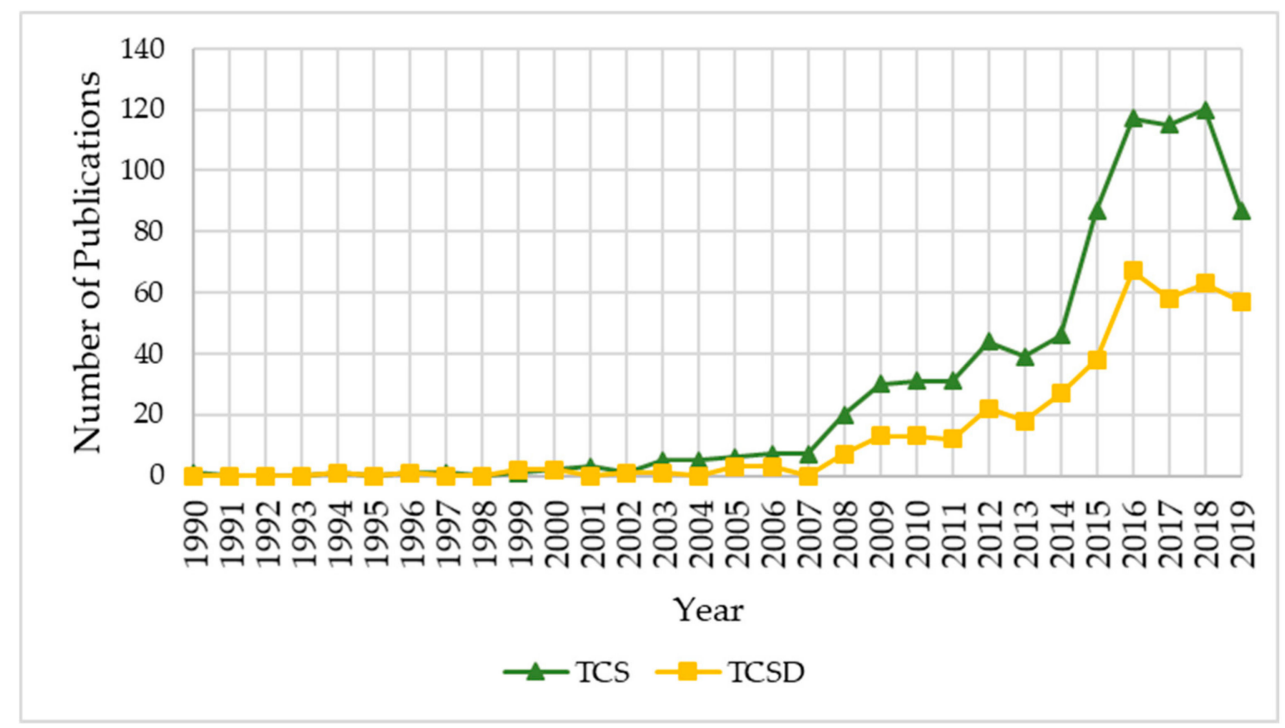

Figure 6. The annual number of publications on TCS and TCSD in Web of Science (WoS). Source: Own elaboration based on data from WoS 2019. The green line in the plot shows the number of publications per year in WoS on TCS; the yellow line indicates the annual number of research articles on TCSD.

Table 1. General citation structure in TCS and TCSD.

\begin{tabular}{ccccc}
\hline \multicolumn{5}{c}{ TCS } \\
\hline $\begin{array}{c}\text { Number of } \\
\text { Citations }\end{array}$ & No of Articles & $\begin{array}{c}\text { Accumulated No } \\
\text { of Articles }\end{array}$ & \% Articles & $\begin{array}{c}\text { \% Accumulated } \\
\text { Articles }\end{array}$ \\
\hline 500 & 1 & 1 & $0.12 \%$ & $0.12 \%$ \\
$\geq 250$ & 0 & 1 & $0.00 \%$ & $0.12 \%$ \\
$\geq 100$ & 6 & 7 & $0.74 \%$ & $0.87 \%$ \\
$\geq 50$ & 17 & 24 & $2.10 \%$ & $2.97 \%$ \\
$\geq 25$ & 37 & 61 & $4.58 \%$ & $7.55 \%$ \\
$\geq 10$ & 67 & 128 & $8.29 \%$ & $15.84 \%$ \\
$<10$ & 680 & 808 & $84.16 \%$ & $100.00 \%$ \\
\hline & & TCSD & & \\
\hline 500 & 1 & 1 & $0.24 \%$ & $0.24 \%$ \\
$\geq 250$ & 0 & 1 & $0.00 \%$ & $0.24 \%$ \\
$\geq 100$ & 3 & 4 & $0.73 \%$ & $0.98 \%$ \\
$\geq 50$ & 11 & 15 & $2.69 \%$ & $3.67 \%$ \\
$\geq 25$ & 14 & 29 & $3.42 \%$ & $7.09 \%$ \\
$\geq 10$ & 39 & 68 & $9.54 \%$ & $16.63 \%$ \\
$<10$ & 341 & 409 & $83.37 \%$ & $100.00 \%$ \\
\hline
\end{tabular}

Source: Own elaboration based on data from WoS 2019.

\subsection{Analysis of the Most Cited Articles on TCS and TCSD}

Table 2 displays the most cited articles and some specific characteristics. This information helps to identify which of all the published articles are the most influential [32] in both TCS and TCSD. 
Table 2. Top 20 most cited papers on TCS and top 10 most cited papers on TCSD.

\begin{tabular}{|c|c|c|c|c|c|c|c|}
\hline \multicolumn{8}{|c|}{ Most Cited Papers on TCS } \\
\hline $\mathbf{R}$ & Journal & NC & Article & Authors & Year & $\mathrm{CY}$ & Main Results \\
\hline 1 & $\mathrm{TM}$ & 994 & Marketing the competitive destination of the future & Buhalis, D. & 2000 & 49.7 & Strategic marketing techniques of tourism destinations. \\
\hline 2 & TEE & 249 & $\begin{array}{l}\text { Is community-based ecotourism a good use of biodiversity } \\
\text { conservation funds? }\end{array}$ & Kiss, A. & 2004 & 15.56 & Conditions to be effective, efficient and sustainable. \\
\hline 3 & $\mathrm{TM}$ & 243 & $\begin{array}{l}\text { Environmental management of a tourist destination-A } \\
\text { factor of tourism competitiveness }\end{array}$ & Mihalic, T. & 2000 & 12.15 & $\begin{array}{l}\text { Increasing environmental competitiveness through a } \\
\text { management and marketing approach. }\end{array}$ \\
\hline 4 & $\mathrm{TM}$ & 165 & The persistence of the sun and sand tourism model & $\begin{array}{l}\text { Aguilo, E.; Alegre, J.; } \\
\text { Sard, M. }\end{array}$ & 2005 & 11 & $\begin{array}{l}\text { Adaptation of the destination's tourist model to environmental } \\
\text { sustainability. }\end{array}$ \\
\hline 5 & $\mathrm{TM}$ & 163 & $\begin{array}{l}\text { Strategic success in winter sports destinations: a sustainable } \\
\text { value creation perspective }\end{array}$ & Flagestad, A.; Hope, C.A. & 2001 & 8.58 & $\begin{array}{l}\text { Two strategic models considering competitive advantage and } \\
\text { sustainable tourism. }\end{array}$ \\
\hline 6 & PS & 134 & $\begin{array}{c}\text { Assessing a voluntary environmental initiative in the } \\
\text { developing world: The Costa Rican Certification for } \\
\text { Sustainable Tourism }\end{array}$ & Rivera, J. & 2002 & 7.44 & $\begin{array}{c}\text { Relationship between participation and differentiation } \\
\text { advantage benefits. }\end{array}$ \\
\hline 7 & BJM & 103 & $\begin{array}{l}\text { The influence of stakeholders on the environmental strategy } \\
\text { of service firms: The moderating effects of complexity, } \\
\text { uncertainty and munificence }\end{array}$ & $\begin{array}{l}\text { Rueda-Manzanares, A.; } \\
\text { Aragon-Correa, J.A.; } \\
\text { Sharma, S. }\end{array}$ & 2008 & 8.58 & $\begin{array}{l}\text { Relationship between integration capability and } \\
\text { environmental strategy. }\end{array}$ \\
\hline 8 & $\mathrm{TM}$ & 98 & $\begin{array}{l}\text { Resources and capabilities as drivers of hotel environmental } \\
\text { marketing strategy: Implications for competitive advantage } \\
\text { and performance }\end{array}$ & $\begin{array}{l}\text { Leonidou, L.C.; Leonidou, } \\
\text { C.N.; Fotiadis, T.A.; } \\
\text { Zeriti, A. }\end{array}$ & 2013 & 14 & $\begin{array}{l}\text { Model of drivers and outcomes of marketing strategies } \\
\text { in Greece. }\end{array}$ \\
\hline 9 & WRCC & 98 & International tourism and climate change & $\begin{array}{l}\text { Scott, D.; Gossling, S.; } \\
\text { Hall, C.M. }\end{array}$ & 2012 & 12.25 & $\begin{array}{l}\text { Relationships between climate change and the international } \\
\text { tourism system. }\end{array}$ \\
\hline 10 & $\mathrm{TM}$ & 98 & $\begin{array}{c}\text { From contents to processes: Versus a dynamic destination } \\
\text { management model (DDMM) }\end{array}$ & Sainaghi, R. & 2006 & 7 & DDMM focused on management processes. \\
\hline 11 & ATR & 88 & Rethinking standards from green to sustainable & Font, X.; Harris, C. & 2004 & 5.5 & $\begin{array}{l}\text { Success and challenges of tourism certification programs in } \\
\text { developing countries. }\end{array}$ \\
\hline 12 & $\mathrm{TM}$ & 86 & $\begin{array}{l}\text { Responsible tourism management: The missing link } \\
\text { between business owners' attitudes and behaviour in the } \\
\text { Cape Town tourism industry }\end{array}$ & Frey, N.; George, R. & 2010 & 8.6 & $\begin{array}{l}\text { Attitudes of tourism business owners towards responsible } \\
\text { tourism management practices. }\end{array}$ \\
\hline 13 & EI & 83 & $\begin{array}{l}\text { Sustainable tourism indicators as planning tools in } \\
\text { cultural destinations }\end{array}$ & $\begin{array}{l}\text { Lozano-Oyola, M.; Javier } \\
\text { Blancas, F.; Gonzalez, M.; } \\
\quad \text { Caballero, R. }\end{array}$ & 2012 & 10.38 & Indicator system to evaluate sustainable tourism. \\
\hline 14 & $\mathrm{TM}$ & 80 & $\begin{array}{l}\text { Tourism, product development and product diversification } \\
\text { in destinations }\end{array}$ & Benur, A.M.; Bramwell, B. & 2015 & 16 & Two conceptual framework with strategic options. \\
\hline 15 & $\mathrm{TM}$ & 70 & $\begin{array}{l}\text { Different tourists to different destinations. Evidence from } \\
\text { spatial interaction models }\end{array}$ & Marrocu, E.; Paci, R. & 2013 & 10 & $\begin{array}{l}\text { Identification of tourism flows and the dependency of } \\
\text { neighbouring provinces. }\end{array}$ \\
\hline 16 & IJSIM & 69 & Hotel networks and social capital in destination marketing & $\begin{array}{l}\text { Grangsjo, Y.V.; } \\
\text { Gummesson, E. }\end{array}$ & 2006 & 4.93 & $\begin{array}{l}\text { Improving competitive position through a competitors' } \\
\text { co-operation local network. }\end{array}$ \\
\hline
\end{tabular}


Table 2. Cont

\begin{tabular}{|c|c|c|c|c|c|c|c|}
\hline \multicolumn{8}{|c|}{ Most Cited Papers on TCS } \\
\hline $\mathbf{R}$ & Journal & NC & Article & Authors & Year & $\mathrm{CY}$ & Main Results \\
\hline 17 & $\mathrm{TM}$ & 67 & Building dynamic capabilities through knowledge resources & Nieves, J.; Haller, S. & 2014 & 11.17 & RBV applied to the hotel industry \\
\hline 18 & $\mathrm{TM}$ & 67 & $\begin{array}{l}\text { Economic incentives for tourism firms to undertake } \\
\text { voluntary environmental management }\end{array}$ & $\begin{array}{l}\text { Blanco, E.; } \\
\text { Rey-Maquieira, J.; } \\
\text { Lozano, J. }\end{array}$ & 2009 & 6.09 & $\begin{array}{l}\text { Consequences of public policies promoting } \\
\text { environmental actions. }\end{array}$ \\
\hline 19 & $\mathrm{TM}$ & 66 & $\begin{array}{l}\text { Business model innovation and business concept } \\
\text { innovation as the context of incremental innovation and } \\
\text { radical innovation }\end{array}$ & Souto, J.E. & 2015 & 13.2 & $\begin{array}{l}\text { Two forms of innovation related with sustainable } \\
\text { competitive advantage. }\end{array}$ \\
\hline 20 & F & 66 & $\begin{array}{l}\text { Confronting tourism's environmental paradox: } \\
\text { Transitioning for sustainable tourism }\end{array}$ & $\begin{array}{l}\text { Williams, P.W.; } \\
\text { Ponsford, I.F. }\end{array}$ & 2009 & 6 & Transformation of tourism towards greater sustainability \\
\hline \multicolumn{8}{|c|}{ Most cited papers on TCSD } \\
\hline 1 & $\mathrm{TM}$ & 994 & Marketing the competitive destination of the future & Buhalis, D. & 2000 & 49.7 & Strategic marketing techniques of tourism destinations. \\
\hline 2 & $\mathrm{TM}$ & 243 & $\begin{array}{l}\text { Environmental management of a tourist destination-A } \\
\text { factor of tourism competitiveness }\end{array}$ & Mihalic, T. & 2000 & 12.15 & $\begin{array}{l}\text { Increasing environmental competitiveness through a } \\
\text { management and marketing approach. }\end{array}$ \\
\hline 3 & $\mathrm{TM}$ & 165 & The persistence of the sun and sand tourism model & $\begin{array}{l}\text { Aguilo, E.; Alegre, J.; } \\
\text { Sard, M. }\end{array}$ & 2005 & 11 & $\begin{array}{l}\text { Adaptation of the destination's tourist model to environmental } \\
\text { sustainability. }\end{array}$ \\
\hline 4 & $\mathrm{TM}$ & 163 & $\begin{array}{l}\text { Strategic success in winter sports destinations: a sustainable } \\
\text { value creation perspective }\end{array}$ & Flagestad, A.; Hope, C.A. & 2001 & 8.58 & $\begin{array}{l}\text { Two strategic models considering competitive advantage and } \\
\text { sustainable tourism. }\end{array}$ \\
\hline 5 & WRCC & 98 & International tourism and climate change & $\begin{array}{l}\text { Scott, D.; Gossling, S.; } \\
\text { Hall, C.M. }\end{array}$ & 2012 & 12.25 & $\begin{array}{l}\text { The relationships between climate change and the international } \\
\text { tourism system. }\end{array}$ \\
\hline 6 & $\mathrm{TM}$ & 98 & $\begin{array}{l}\text { From contents to processes: Versus a dynamic destination } \\
\text { management model (DDMM) }\end{array}$ & Sainaghi, R. & 2006 & 7 & Dynamic model of destination management. \\
\hline 7 & $\mathrm{TM}$ & 86 & $\begin{array}{l}\text { Responsible tourism management: The missing link } \\
\text { between business owners' attitudes and behaviour in the } \\
\text { Cape Town tourism industry }\end{array}$ & Frey, N.; George, R. & 2010 & 8.6 & $\begin{array}{l}\text { Attitudes of tourism business owners towards responsible } \\
\text { tourism management practices. }\end{array}$ \\
\hline 8 & EI & 83 & $\begin{array}{l}\text { Sustainable tourism indicators as planning tools in } \\
\text { cultural destinations }\end{array}$ & $\begin{array}{l}\text { Lozano-Oyola, M.; Javier } \\
\text { Blancas, F.; Gonzalez, M.; } \\
\text { Caballero, R. }\end{array}$ & 2012 & 10.38 & Indicator system to evaluate sustainable tourism. \\
\hline 9 & $\mathrm{TM}$ & 80 & $\begin{array}{l}\text { Tourism, product development and product diversification } \\
\text { in destinations }\end{array}$ & Benur, A.M.; Bramwell, B. & 2015 & 16 & Two conceptual framework with strategic options. \\
\hline 10 & $\mathrm{TM}$ & 70 & $\begin{array}{l}\text { Different tourists to different destinations. Evidence from } \\
\text { spatial interaction models }\end{array}$ & Marrocu, E.; Paci, R. & 2013 & 10 & $\begin{array}{c}\text { Identification of tourism flows and the dependency of } \\
\text { neighbouring provinces. }\end{array}$ \\
\hline
\end{tabular}

Source: Own elaboration based on data from WoS 2019. R: ranking; NC: total number of citation; CY: citations per year. TM: Tourism Management; TEE: Trends In Ecology \& Evolution; PS: Policy Sciences; BJM: British Journal of Management; WRCC: Whiley Interdisciplinary Reviews-Climate Change; ATR: Annals of Tourism Research; EI: Ecological Indicators; IJSIM: International Journal of Service Industry Management; F: Futures. 
The variables we use to show the influence and quality of the articles are the total number of citations together with the number of citations per year. The most cited article on TCS is that by Buhalis (2000) [17], with 994 total citations and with the highest number of citations per year (49.70). The aim of this paper is to combine competitiveness and environmental management. The second most cited paper is that by Kiss (2004) [45], with 249 citations and 15.56 citations per year. Although this paper analyzes the so-called "Community-based ecotourism-CBET", the approach it takes is to study the link between economically successful projects and sustainable actions. Finally, the article by Mihalic (2000) [13] is the third most cited, with 243 citations in total and 12.15 citations per year. In that paper, the concept of environmental management in tourism destinations is studied along with tourism competitiveness.

As for TCSD research, $80 \%$ of the top 10 most cited articles were published in Tourism Management (Table 2). The three most cited articles on the TCSD topic are Buhalis (2000) [17] with 994 citations, Mihalic (2000) [13] with 243 citations, and Aguiló et al., (2005) [46] with 165 citations.

On both levels, the most cited paper is by Buhalis (2000) [17], whose research emphasizes the need to combine strategic objectives with the sustainability of the destinations' resources and is therefore aligned with our TCS and TCSD approaches.

\subsection{Analysis of the Journals on TCS and TCSD}

A list of journals with the highest number of influential papers is presented in Table 3.

Table 3. The top 20 journals related to TCS and the top 10 journals related TCSD.

\begin{tabular}{|c|c|c|c|c|c|c|c|}
\hline \multicolumn{8}{|c|}{ TCS } \\
\hline $\mathbf{R}$ & Journals & APTCS & HTCS & TAP & PCTCS & $\%$ APTCS & IF \\
\hline 1 & $S$ & 49 & 7 & 14,518 & 2.98 & 0.34 & 2.59 \\
\hline 2 & $\mathrm{TM}$ & 27 & 22 & 3838 & 97.11 & 0.70 & 6.01 \\
\hline 3 & JST & 16 & 11 & 958 & 17.94 & 1.67 & 3.40 \\
\hline 4 & CIT & 15 & 7 & 966 & 10.2 & 1.55 & 3.39 \\
\hline 5 & IJTR & 13 & 5 & 690 & 9 & 1.88 & 2.27 \\
\hline 6 & $\mathrm{JCP}$ & 12 & 6 & 16,794 & 7.33 & 0.07 & 6.40 \\
\hline 7 & TSEE & 11 & 1 & 149 & 0.64 & 7.38 & - \\
\hline 8 & MZSGIHJDS & 10 & 0 & 686 & 0 & 1.46 & - \\
\hline 9 & PSBS & 10 & 4 & 28,762 & 9.4 & 0.03 & - \\
\hline 10 & IJCHM & 9 & 5 & 1078 & 13.56 & 0.83 & 3.95 \\
\hline 11 & PRTPC & 9 & 1 & 406 & 0.44 & 2.22 & - \\
\hline 12 & $\mathrm{AE}$ & 8 & 4 & 873 & 5.3 & 0.92 & 1.23 \\
\hline 13 & IJHM & 8 & 4 & 1554 & 9.13 & 0.51 & 4.47 \\
\hline 14 & PEF & 8 & 5 & 3373 & 5 & 0.24 & - \\
\hline 15 & WHTT & 8 & 2 & 292 & 1.63 & 2.74 & - \\
\hline 16 & AEBMR & 7 & 1 & 5454 & 0.14 & 0.13 & - \\
\hline 17 & EJTR & 6 & 1 & 209 & 1 & 2.87 & - \\
\hline 18 & IMSCSSA & 6 & 1 & 3576 & 0.17 & 0.17 & - \\
\hline 19 & JDMM & 6 & 3 & 355 & 5.67 & 1.69 & - \\
\hline 20 & JTR & 6 & 5 & 727 & 20.17 & 0.83 & 5.33 \\
\hline \multicolumn{8}{|c|}{ TCSD } \\
\hline 1 & $S$ & 36 & 6 & 14,518 & 3.39 & $0.25 \%$ & 2.59 \\
\hline 2 & $\mathrm{TM}$ & 18 & 15 & 3838 & 122.78 & $0.47 \%$ & 6.01 \\
\hline 3 & JST & 11 & 8 & 958 & 20.09 & $1.15 \%$ & 3.40 \\
\hline 4 & IJTR & 10 & 4 & 690 & 7.60 & $1.45 \%$ & 2.27 \\
\hline 5 & CIT & 8 & 4 & 966 & 9.88 & $0.83 \%$ & 3.39 \\
\hline
\end{tabular}


Table 3. Cont.

\begin{tabular}{cccccccc}
\hline 6 & JTR & 6 & 5 & 727 & 20.17 & $0.83 \%$ & 5.33 \\
7 & IJCHM & 4 & 3 & 1078 & 21.00 & $0.37 \%$ & 3.95 \\
8 & WRCC & 1 & 1 & 550 & 98.00 & $0.18 \%$ & 7.05 \\
9 & EI & 1 & 1 & 5280 & 83.00 & $0.02 \%$ & 4.49 \\
10 & IJSIM & 1 & 1 & 461 & 69.00 & $0.22 \%$ & - \\
\hline
\end{tabular}

Source: Own elaboration based on data from WoS 2019. R: ranking; APTCS: articles published on TCS; HTCS: the h-index in the area of TCS; TAP: total articles published; PCTCS: average citations of articles on TCS. \%APTCS: percentage of articles published on TCS (APTCS/TAP); IF: impact factor. TCSD refers to $\mathrm{T}+\mathrm{S}+\mathrm{C}+\mathrm{Cluster} / \mathrm{Destination}$. APTCSD: articles published on TCSD; HTCSD: the h-index in the area of TCSD; PCTCSD: average citations of articles on TCSD. \%APTCSD: percentage of articles published on TCSD (APTCSD/TAP). Journals: S: Sustainability; TM: Tourism Management; JST: Journal of Sustainable Tourism; CIT: Current Issues in Tourism; IJTR: International Journal of Tourism Research; JCP: Journal of Cleaner Production; TSEE: Tourism in South East Europe; MZSGIHJDS: Medunarodni Znanstveni Simpozij Gospodarstvo Istocne Hrvatske Jucer Danas Sutra; PSBS: Procedia Social and Behavioral Sciences; IJCHM: International Journal of Contemporary Hospitality Management; PRTPC: Pasos Revista de Turismo y Patrimonio Cultural; AE: Amfiteatru Economic; IJHM: International Journal of Hospitality Management; PEF: Procedia Economics and Finance; WHTT: Worldwide Hospitality and Tourism Themes; AEBMR: AEBMR Advances in Economics Business and Management Research; EJTR: European Journal of Tourism Research; IMSCSSA: International Multidisciplinary Scientific Conferences on Social Sciences and Arts; JDMM: Journal of Destination Marketing Management; JTS: Journal of Travel Research; WRCC: Wiley Interdisciplinary Reviews-Climate Change; EI: Ecological Indicators; IJSIM: International Journal Of Service Industry Management.

The journals are ranked in terms of the number of articles published on TCS (APTCS). The 808 articles on TCS were published in a total of 527 journals, and the 409 articles on TCSD were published in a total of 287 journals. Of all the sources publishing articles on TCS, $70 \%$ published only one article in their journal. Only nine journals published 10 or more articles. We can see that the top 10 journals have published 172 articles, representing $21.28 \%$ of the APTCS. The top three journals in terms of APTCS are Sustainability, Tourism Management and Journal of Sustainable Tourism.

Another measurement of the quality of the journal is the h-index [47], which represents the number (h) of papers published by an author/journal/institution that have received at least $\mathrm{h}$ citations. The top three journals also have the highest h-index (H-TCS), albeit in a different order. Tourism Management tops this ranking, Journal of Sustainable Tourism is second, and Sustainability is joint third with Current Issues in Tourism.

Looking at the top 20 journals, the journals with the highest number of citations per article published related to TCS (PCTCS) are Tourism Management (97.11), Journal of Sustainable Tourism (17.94) and International Journal of Contemporary Hospitality Management (13.56).

Finally, taking into account the top 20 journals, those with the highest percentage of articles published on TCS (\%APTCS) are Tourism in South East Europe (7.38), International Journal of Tourism Research (1.88) and Journal of Tourism Management (1.67).

In the case of TCS research, the main categories of these publications are Hospitality, Leisure Sport and Tourism (46.27\%); Environmental Studies (18.07\%); Management (17.83\%); Green and Sustainable Science and Technology (14.70\%); Economics (14.46\%); Environmental Sciences (13.25\%); and Business (10.60\%).

The three main journals by number of publications on TCSD are: Sustainability, which focuses on experimental and theoretical research related to natural sciences, social sciences and humanities that examines the impact of global change and development; Tourism Management (the journal with the highest number of citations), which focuses on the planning and management of travel and tourism; and Journal of Sustainable Tourism, which focuses on the analysis of the relationships between tourism and sustainable development. The journal with the highest h-index is Tourism Management (15). In addition, $23.4 \%$ of the total articles (409) have been published in one of the top 10 journals. The journals with the highest number of citations per published article related to TCSD (PCTCSD) are Tourism Management (122.78), Wiley Interdisciplinary Reviews-Climate Change (98), and Ecological Indicators (83).

In the case of TCSD research, the main categories of these publications are Hospitality, Leisure, Sport and Tourism (45.85\%); Environmental Studies (17.80\%); Management (17.80\%); Green and 
Sustainable Science and Technology (14.63\%); Economics (14.39\%); Environmental Sciences (13.17\%); and Business (10.73\%). Furthermore, $72.1 \%$ of the journals have published only one article; $26.8 \%$ have published between 2 and 10; $0.7 \%$ have published between 11 and 20; and, lastly, $0.3 \%$ have published more than 20 articles (Table 3).

\subsection{Keyword Analysis}

As the keywords selected by the authors indicate the core content and subject of the article, they can reveal trends in research and the most significant themes in a specific area. In this section, we show the keywords that appear together in the same article, or keyword co-occurrence. When working with keywords, the Occurrences attribute indicates the number of documents in which a keyword occurs ([48], p. 32).

By examining the 808 papers in TCS research, the analysis reveals the existence of 2922 keywords. VOSviewer treats this information graphically, as can be seen in Figure 7. The most frequent keywords by cluster are: Tourism (yellow cluster), Competitiveness (red cluster), Sustainable tourism (purple cluster), Management (green cluster), and Model (blue cluster).

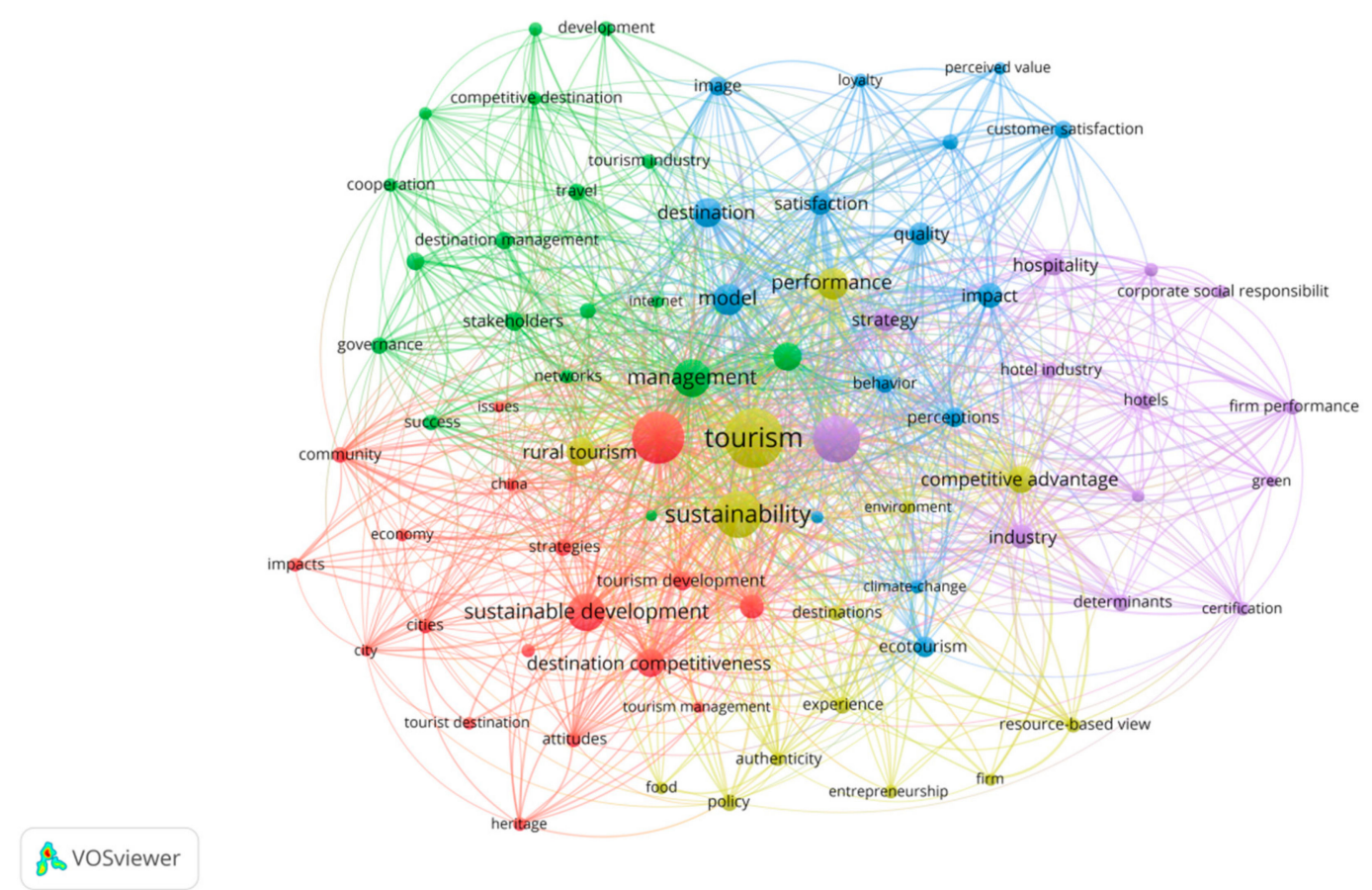

Figure 7. Co-occurrence network of author keywords for TCS. The figure includes the 78 keywords with the most frequent occurrences, of the 2922 total keywords, which meet a minimum threshold of 10 occurrences.

Table 4 shows the top 20 keywords in TCS, as well as occurrences (frequency) and co-occurrences (total link strength).

In the case of TCSD research, the analysis reveals the existence of 1158 keywords. Figure 8 shows the main keywords, which are organized into six clusters, where the most important compounds are Sustainable Development (red cluster), Destination (cluster in green), Sustainable Tourism (dark blue cluster), Competitiveness (yellow cluster), Tourism (purple cluster), and Sustainability (light blue cluster).

Table 5 shows the top 10 keywords in TCSD, as well as occurrences (frequency) and co-occurrences link (total link strength). In terms of occurrence and co-occurrences, the most important keywords are Tourism, Sustainability and Competitiveness. 
Table 4. The top keyword co-occurrence of TCS publications. Source: Own elaboration based on data from WoS 2019. R: Rank; Oc: keyword occurrences; Co: keyword co-occurrences link.

\begin{tabular}{lccc}
\hline $\mathbf{R}$ & Keyword & Oc & Co \\
\hline 1 & Tourism (C4) & 187 & 505 \\
2 & Competitiveness (C1) & 147 & 502 \\
3 & Sustainable tourism (C5) & 123 & 376 \\
4 & Sustainability & 122 & 411 \\
5 & Sustainable development & 82 & 157 \\
6 & Management (C2) & 80 & 337 \\
7 & Performance & 58 & 242 \\
8 & Model (C3) & 56 & 227 \\
9 & Destination & 51 & 197 \\
10 & Destination & 49 & 179 \\
11 & competitiveness & 49 & 147 \\
12 & Rural tourism & 47 & 165 \\
13 & Innovation & 43 & 180 \\
14 & Competitive advantage & 38 & 148 \\
15 & Impact & 36 & 181 \\
16 & Industry & 35 & 166 \\
17 & Perspective & 34 & 152 \\
18 & Satisfaction & 34 & 128 \\
19 & Strategy & 33 & 130 \\
20 & Quality & 30 & 136 \\
\hline
\end{tabular}

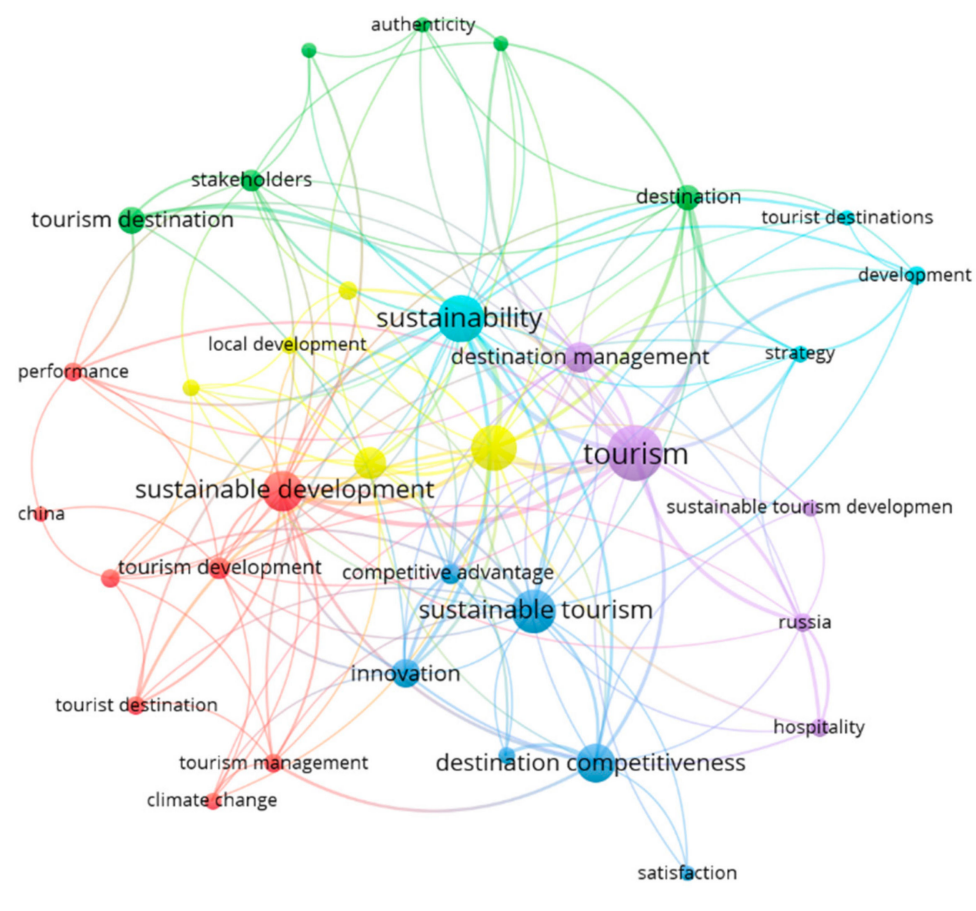

Figure 8. Co-occurrence network of author keywords in publications related to TCSD. The figure includes the 34 keywords with the most frequent occurrences of the 1158 total keywords which meet a minimum threshold of five occurrences. 
Table 5. The top keyword co-occurrence for TCSD publications. Source: Own elaboration based on data from WoS 2019. R: Rank; Oc: keyword occurrences; Co: keyword co-occurrences link.

\begin{tabular}{cccc}
\hline $\mathbf{R}$ & Keyword & Oc & Co \\
\hline 1 & Tourism & 64 & 81 \\
2 & Sustainability & 47 & 67 \\
3 & Competitiveness & 43 & 62 \\
4 & Sustainable development & 35 & 39 \\
5 & Sustainable Tourism & 39 & 27 \\
6 & Destination & 32 & 26 \\
7 & competitiveness & 13 & 25 \\
8 & Destination & 17 & 25 \\
9 & Innovation & 19 & 20 \\
10 & Destination Management & 21 & 19 \\
\hline
\end{tabular}

\subsection{Reference, Journal, and Author Co-Citation Analysis}

If two items (whether author, paper or journal) are cited together by a third (all of them are present in the reference sections of other articles), there is a co-citation relationship between them. The correlation between the items can thus be identified [49]. Again, by using the concept of nodes, clusters and lines, VOSviewer helps to graphically visualize the existing relationships in an area of research.

The distance between two journals, authors or references indicates the relatedness of the journals, authors, or references in terms of co-citation links. In general, the closer two journals, authors, or references are to each other, the stronger their relatedness. The strongest co-citation links between journals, authors or references are also represented by lines [48].

The first approach is co-citation network analysis, where every node represents an individual article and the lines indicate the collaboration relationship and the most frequent research topics relating to TCS. Figure 9 shows the leading articles on TCS in this regard. There are three clusters. In the most cited cluster (red), the paper by Ritchie J.R.B. [50] has been cited 78 times. The second is by Dwyer, L. [51] with 73 citations. And the third, with 71 citations, is by Crouch, G.I. [42]. In the second most important cluster (green), with 66 citations we find Buhalis D. [17], who had the most cited paper in Table 2. Following some way below, is Barney, J. [52] with 32 citations. Lastly, Liu, Z. [53] leads the blue cluster with 27 citations.

First, the co-citation network of references on TCSD (Figure 10) was created, yielding three clusters. The most represented articles form the red cluster: Ritchie, J.R.B. (2003) [50] with 72 citations and total link strength of 286 (ranked second for total link strength and first for citations); and Crouch G.I. (1999) [42] with 66 citations, and total link strength of 275 (ranked third for total link strength and third for citations). In the green cluster is Dwyer, L. (2003) [51] with 68 citations and total link strength of 306 (ranked first for total link strength and second for citations). And in the blue cluster is Liu, Z. (2003) [53], with only 23 citations and total link strength of 106 (ranked $13^{\text {th }}$ for total link strength and $14^{\text {th }}$ for citations); this article analyzes sustainable tourism and addresses six issues-the role of tourism demand, the nature of tourism resources, the imperative of intra-generational equity, the role of tourism in promoting socio-cultural progress, the measurement of sustainability, and the forms of sustainable development. The three most important references are not among the TCSD articles we downloaded and analyzed, because the first two are not in the WoS database and the third does not comply with the search restrictions. The Dwyer, L. (2003) [51] article develops a model of destination competitiveness that enables comparisons between countries and between tourism sector industries. On the other hand, the work by Ritchie, J.R.B. (2003) [50] is a book focused on the tourism destination and the development of a reference model, highlighting the need for a qualitative understanding of the factors that contribute to the success of the destination, through greater competitiveness and ongoing 
sustainability. Lastly, Crouch G.I. (1999) [42] examines the link between social prosperity and tourism using a competitiveness frame of reference.

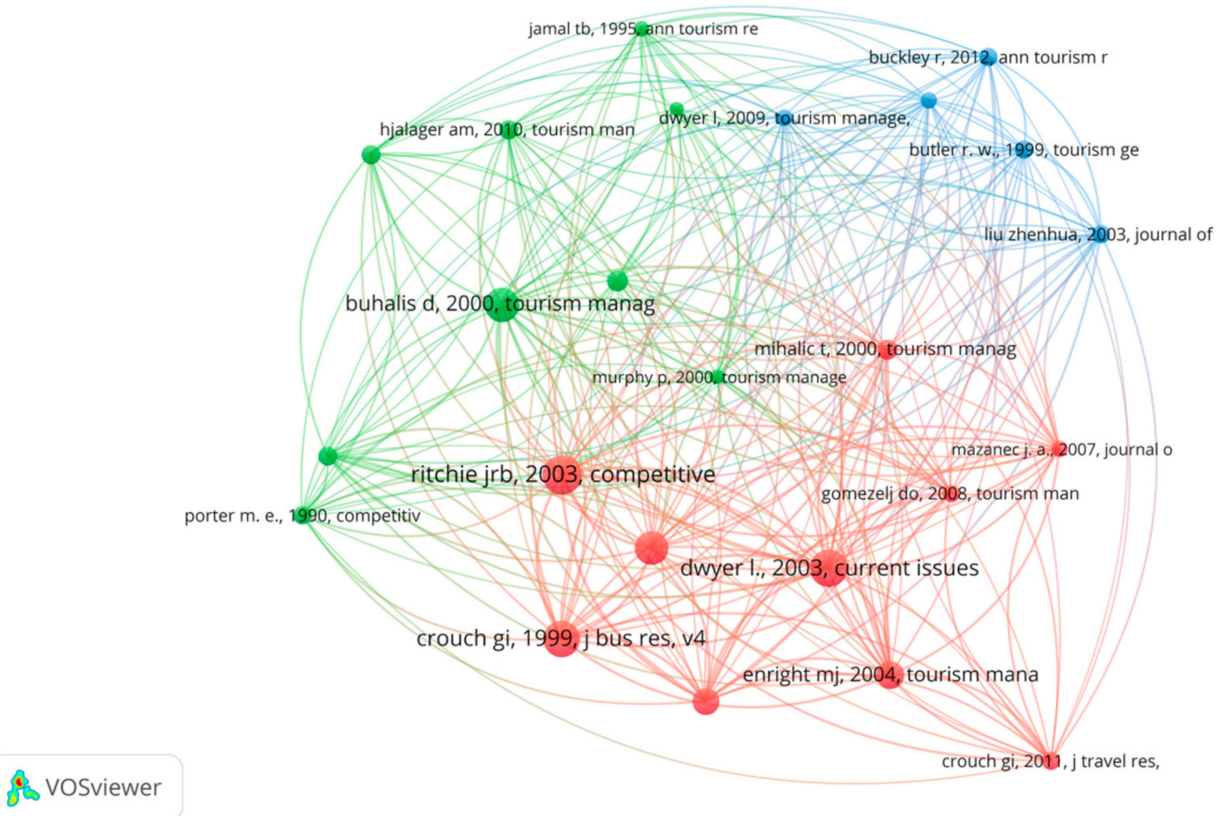

Figure 9. Co-citation of references on TCS: 24 references of the 30,578 cited references which meet the minimum threshold of 20 citations of a reference.

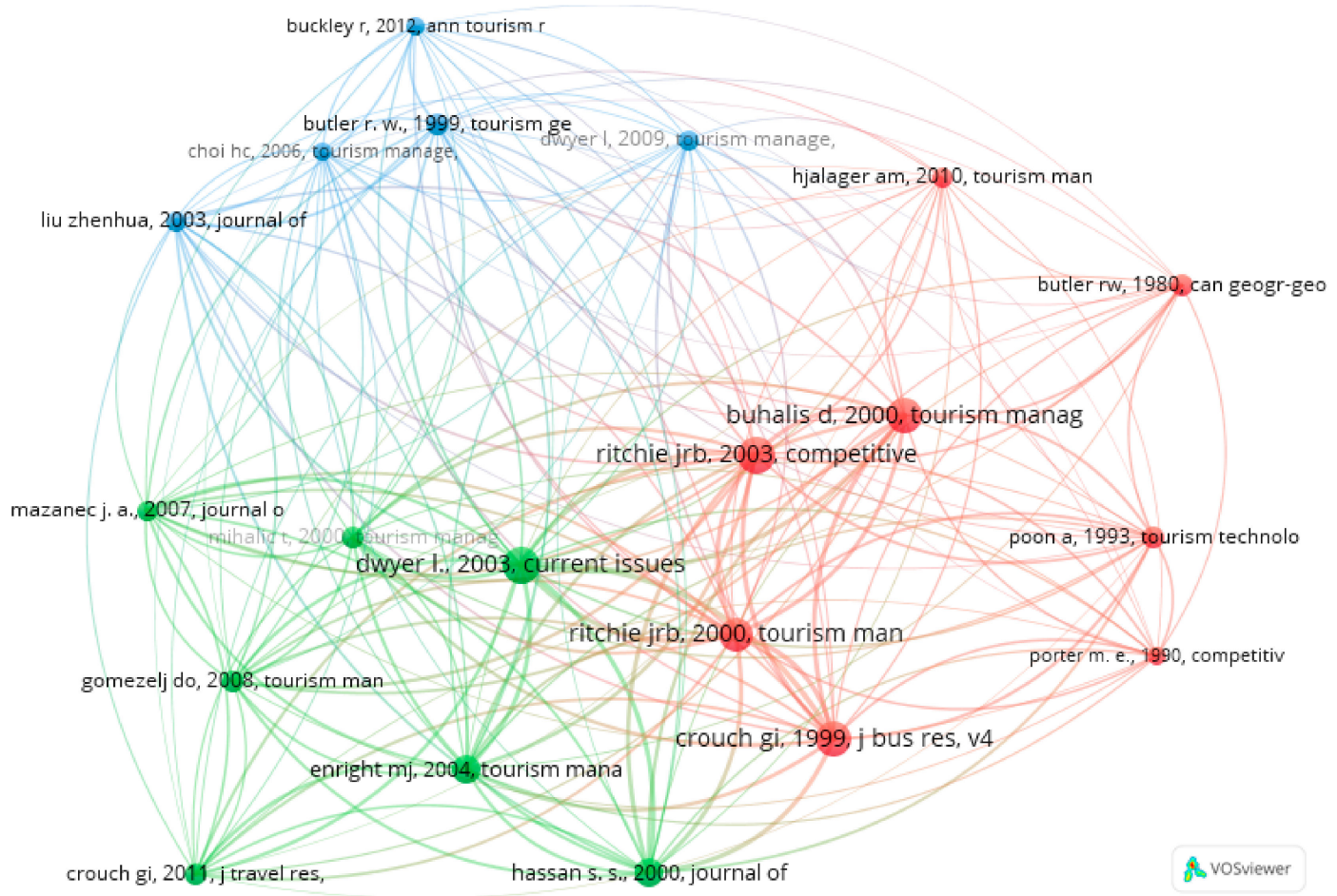

Figure 10. Co-citation of references related to TCSD: 20 references of the 17,886 cited references which meet the minimum threshold of 20 citations of a reference.

The second network we are studying is journal co-citation for TCS (Figure 11). The bigger the node, the more articles a journal has published; also, the distance between the nodes represents the frequency of citation between them. Thus, when two nodes are very close, they have cited one another more times. 
As we can see, the program identifies three main clusters and one residual. Tourism Management is the journal with the most citations (2548) in the green cluster and also the highest link strength $(79,693)$ followed by Annals of Tourism Research (1372 and 48,607, respectively). Regarding the topics of the journals in this cluster, we can see that they are mainly focused on tourism and travel. Journal of Sustainable Tourism (606 and 23,034, respectively) leads the blue cluster, which is mostly focused on sustainability; and in the red cluster, which is made up of management journals, we have International Journal of Hospitality Management, with 422 citations and a total link strength of 16,555.

The residual cluster has only three items. It is located at the bottom of the network, shown in yellow. Two of the three items are journals related to an economics perspective.

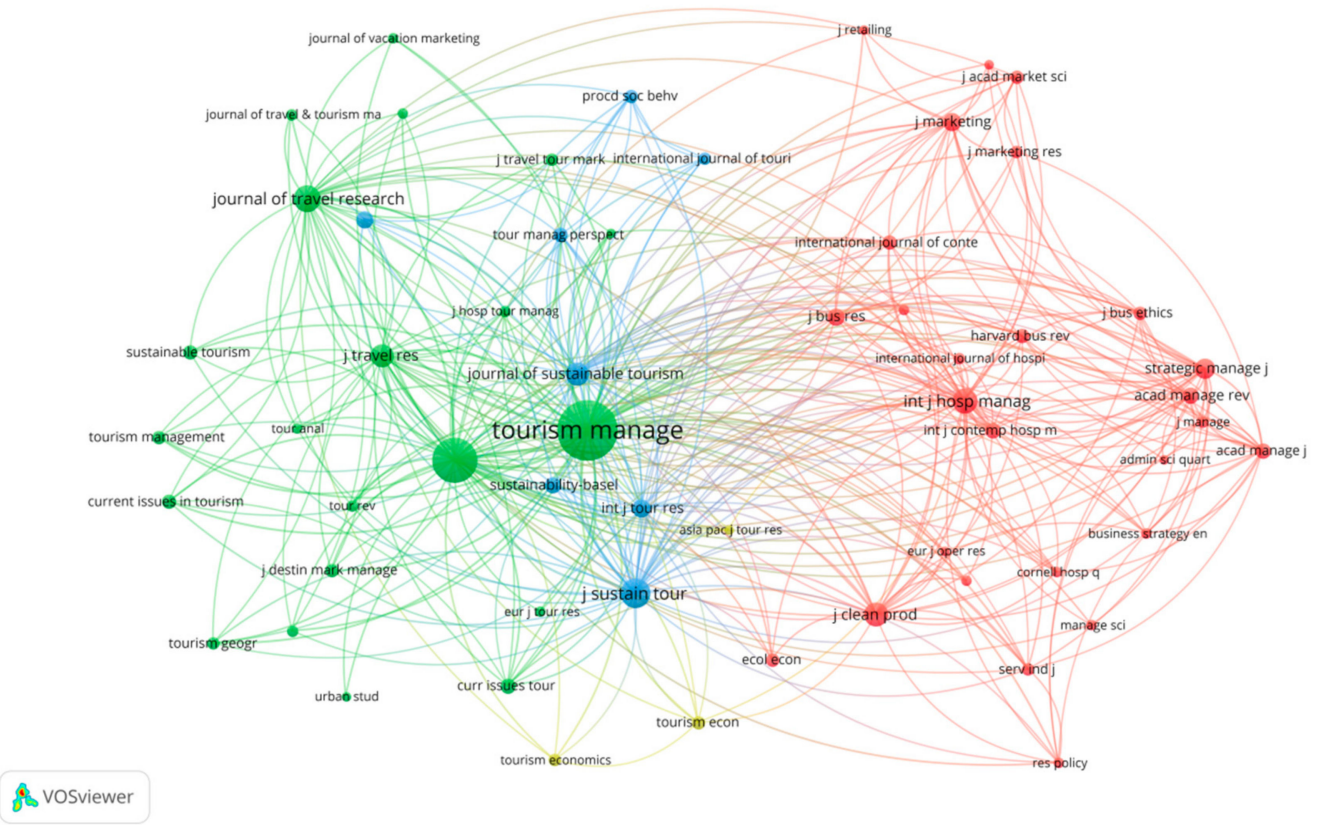

Figure 11. Journal co-citation network for TCS: 59 main journals of the 14,604 cited sources for the 808 publications on TCS which meet the minimum threshold of 60 citations of a cited source.

The analysis of the journal co-citation network for TCSD yields six clusters (Figure 12). The red cluster includes Tourism Management, the journal with the most citations (2022) and the highest link strength $(57,900)$, and focuses on the planning and management of travel and tourism. The green cluster includes Journal of Sustainable Tourism (Citations 444, Link Strength 16,133), which focuses on the analysis of the relationships between tourism and sustainable development. The dark blue cluster includes International Journal of Tourism Research (Citations 179, Link Strength 7575), which focuses on tourism and hospitality research. The yellow cluster includes Annals of Tourism Research (Citations 1108, Link Strength 37,678), which focuses on academic perspectives of tourism and on the development of theoretical constructs. The purple cluster includes the Journal of Destination Marketing \& Management (Citations 3819, Link Strength 112), which focuses on the study of tourism destinations related to aspects of marketing and management, placing them in specific policy, planning, economic, geographical, and historical contexts. Lastly, the light blue cluster includes Tourism Economics (Citations 89, Link Strength 2780), which focuses on the economic and commercial aspects of tourism. These journals are mainly focused on the categories of Hospitality, Leisure, Sport and Tourism, and Environmental Studies. It can also be seen that all clusters are very close to each other, indicating a strong relationship between them.

We can see the third co-citation analysis in Figure 13. The main author network reveals the existence of three clusters. The small differences between the top authors are indicative of the homogeneity in terms of most cited authors, regardless of the cluster they belong to. For instance, 
Dwyer, L. with 202 citations in the blue cluster; followed by Buhalis, D. (181 citations) in the red cluster; Ritchie, J.R.B. (177) in the blue; or Hall, C.M. (175) in the green one.

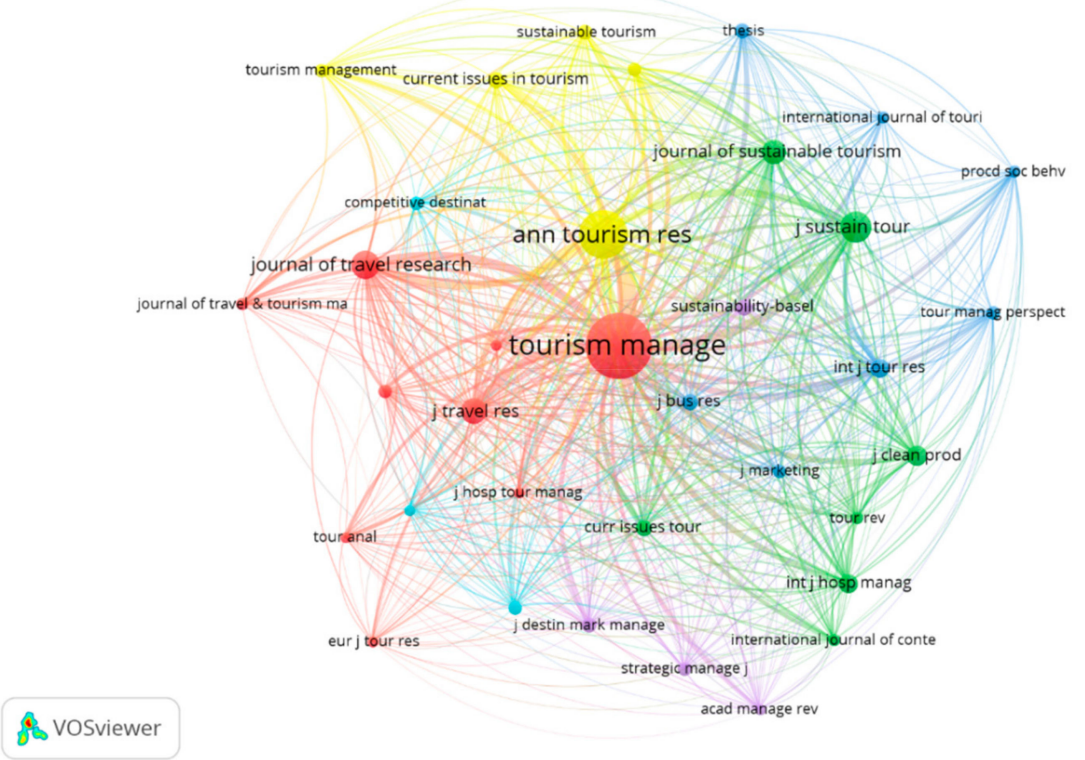

Figure 12. Journal co-citation network for TCSD: 35 main journals of the 8583 cited sources for the 409 publications on TCSD which meet the minimum threshold of 60 citations of a cited source.

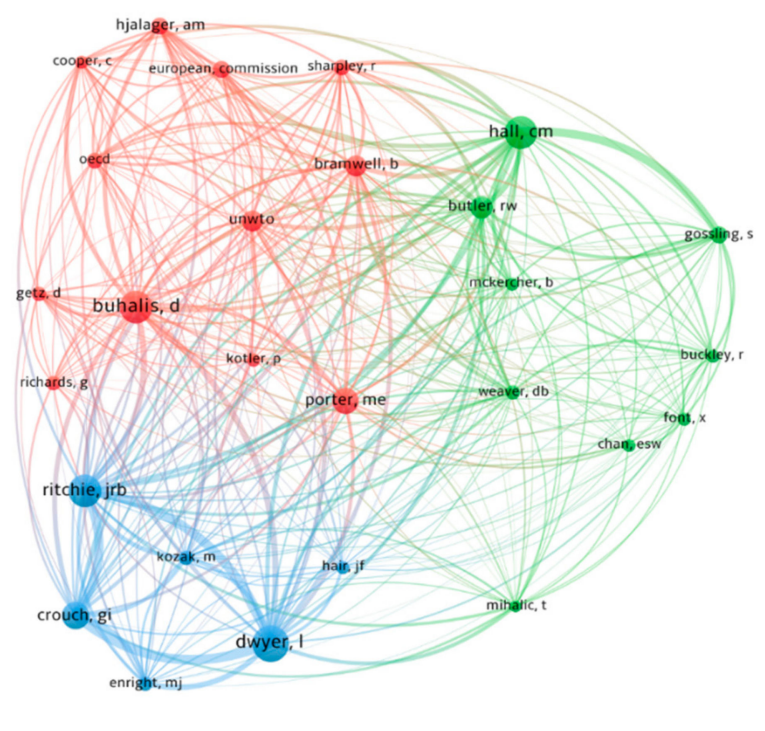

Figure 13. Author co-citation network for TCS: 27 authors of the 20,113 cited authors who meet the minimum threshold of 50 citations.

The predominance of the red cluster is due to the number of items that it contains. It has 12 authors in total, compared to 9 in the green cluster or the 6 in the blue cluster. The authors with the highest link strength are in the blue cluster: Dwyer, L. (1544) and Ritchie, J.R.B. (1487).

Examining the main author of each cluster, we can determine their typical perspective. Dwyer's research focuses on destination competitiveness, most specifically in Serbia. His articles also analyze performance and tourism business strategies. Buhalis' top article on this issue synthesizes models for the strategic marketing of destinations; he explains that the "marketing of destinations should balance the strategic objectives of all stakeholders as well the sustainability of local resources" [3]. In the green cluster, we find Hall, C.M., whose research focuses on international tourism and climate change. 
The author co-citation network for TCSD (Figure 14) illustrates the existence of three clusters. The red cluster consists of 11 authors, of which the predominant author is Buhalis, D. (143 citations and Link Strength 1134). He has 102 publications in WoS, and his research focuses on smart tourism and smart hospitality, social media and mobile marketing, augmented reality, and the management and personalization of experiences enhanced with technology.

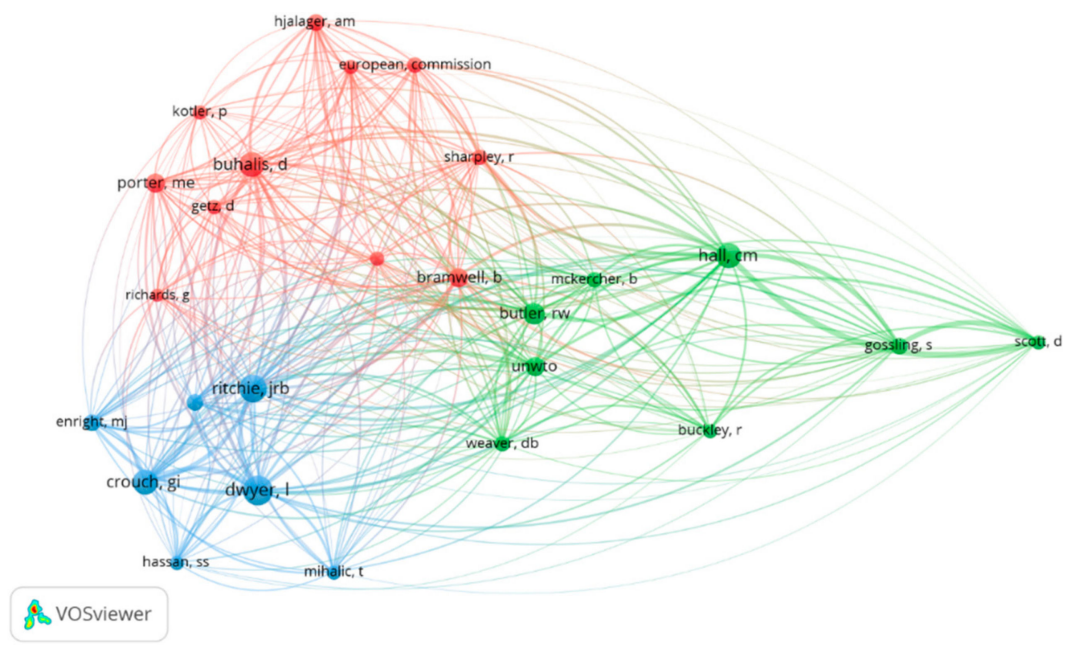

Figure 14. Author co-citation network for TCSD: 26 authors of the 11,709 cited authors who meet the minimum threshold of 40 citations.

In the green cluster, consisting of eight authors, the predominant author is Hall, C.M. (132 citations and Link Strength 1623, which is the top ranking for Link Strength). He has 261 publications in WoS and his studies focus mainly on tourism planning, policy and geography. Another major author in this cluster is Butler, R.W. (99 citations and Link Strength 944), who has 60 publications in WoS on the role of clusters, cooperation and complementarities in the visitor attraction sector, as well as on the geography of tourism.

Lastly, in the blue cluster consisting of seven authors, there are three predominant authors. The first is Dwyer, L. (187 citations and Link Strength 1512, ranked top for citations), whose 97 publications in WoS focus mainly on the areas of tourism economics, management and policy and specifically on the drivers of the competitiveness of tourism destinations. He is followed by Ritchie, J.R.B. (165 citations and Link Strength 1471), whose 63 publications in WoS focus on tourism policy, planning and development, the management of service quality in tourism, the improvement of productivity and competitiveness in the industry, and managing the tourism impact of mega-events and attractions. Lastly, there is Crouch, G.I. (135 citations and Link Strength 1225), with 32 publications in WoS, whose research focuses on destination competitiveness, space tourism, tourism marketing, and tourism consumer behaviour.

\subsection{Bibliographic Coupling of Authors}

Whereas in the analysis of co-citation we looked for whether Article A cited Articles B and C, with bibliographic coupling we are looking for whether A and B cite Article C. In other words, we are counting the number of references that a group of papers has in common.

Figure 15, which depicts this analysis, shows that there is no single author that stands out above the others, regardless of the cluster. This is because almost all the authors have only three publications in common. The top four authors do have a few more, but the differences are not substantial: Pulido-Fernandez, J.I. with seven publications; Dwyer, L. with five; and Buffa, F. and Sainaghi, R. with four. 


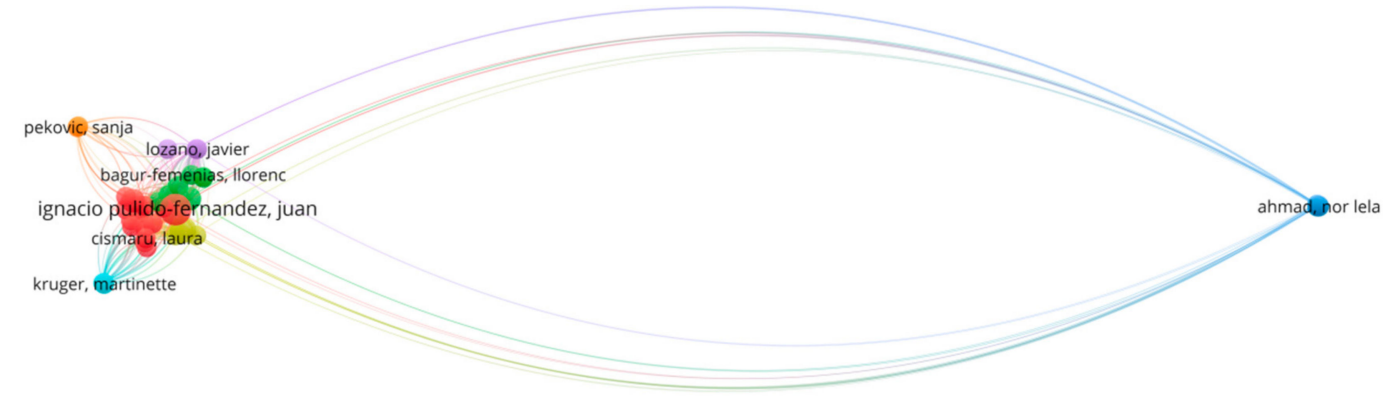

\& vosviewer

Figure 15. Bibliographic coupling of authors in TCS: 36 authors out of the 1861 authors who meet the minimum threshold of three publications.

For the total link strength, the order of the top authors is reversed: First we have Dwyer, L. with 782 and then Pulido-Fernandez, J.I. with 645. They are followed by Mihalic, T. with 620 and Armenski, T. with 604 .

The program has identified seven clusters. The main one is the red cluster, which has 15 items and is led by Pulido-Fernandez, J.I. The second most important cluster is the green one, which has seven items. The next cluster is the dark blue one, comprising four elements. What is striking about this cluster is that its four items are on the right-hand side, far away from the rest and almost superimposed over each other. All four of these authors are located in Malaysian universities and worked together on the articles. The yellow and purple clusters have three items each. Lastly, the light blue and the orange clusters have two elements.

If we examine the predominant authors in the larger clusters, we can see the different perspectives of their studies. In the red cluster we have Pulido-Fernandez, J.I., whose work focuses on sustainable tourism, especially its relationship with performance and growth. In the green cluster we have Buffa, F., focusing on sustainability from the perspective of management practices and business models. In the case of the dark blue cluster, the studies are closely focused on event greening. Although Dwyer, L. is the author with the second highest number of publications, he is located in one of the smallest clusters, namely the yellow one.

According to the analysis of TCSD, there are five clusters (Figure 16): the red cluster, composed of six authors; the green cluster composed of four authors; the blue cluster composed of three authors; the yellow cluster composed of two authors, and the purple cluster composed of two authors. In terms of the number of publications, the list is headed up by Ignacio Pulido-Fernández, J. (Publications 7, Link strength 523); Dwyer, L. (Publications 5, Link strength 732) and Buffa, F. (Publications 4, Link strength 425). In terms of link strength, the list is headed up by Dwyer, L. (Publications 5, Link strength 732); Mihalic, T. (Publications 3, Link strength 586); and Armenski, T. (Publications 3, Link strength 571).

The blue and purple clusters are farthest away from the other clusters, which means that the research topics are less related to the others. These two clusters represent new research themes. On the one hand, Kruger, M. and Saayman M. of North West University in South Africa (purple cluster), focus on research into the motivations, determinants and typology of visitors to different sporting and musical events. On the other hand, Dwyer, L., Armenski, T. and Mihalic, T. from, respectively, the University of New South Wales in Australia, University Novi Sad in Serbia and University of Ljubljana in Slovenia (blue cluster) have developed a Modified Importance-Performance Analysis to assess the importance of different strategic activities aimed at promoting destination competitiveness in Serbia and Slovenia. 


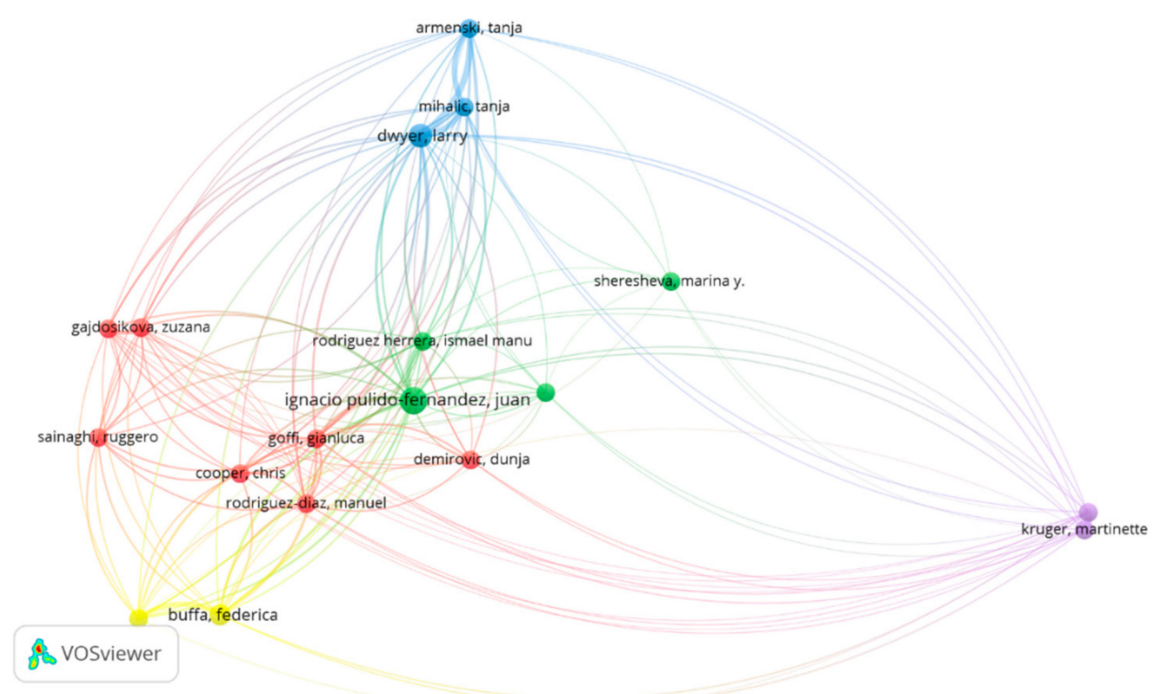

Figure 16. Bibliographic coupling of authors in TCSD: 18 authors out of the 951 authors who meet the minimum threshold of three publications.

\subsection{Country and University Co-Author Analysis}

Finally, we carry out an analysis of co-authorship, which depicts the networks of collaboration between countries and organizations for the two levels that we are studying.

The size of the items (nodes) in this case reflects the relevance of the country or organization in question, and the distance between them indicates the degree of collaboration.

For the TCS level (Figure 17), the program presents us with seven clusters, of which the red one contains the most items and is led by Portugal. We see a fair degree of dispersion in the cooperation between countries. In general, the clustering is quite heterogeneous at first glance, although we do find two clusters of countries in which the relationships are more evident. This is the case with the orange cluster, which brings together the Spanish-speaking countries of Spain, Mexico and Ecuador. The green cluster, on the other hand, contains countries related in terms of their geolocation: Egypt, India, Indonesia, Iran, Malaysia, and Thailand.

The countries that stand out for their contributions to this area of study are Spain (106 publications), China (77), Italy (77), Romania (59), and Croatia (50).

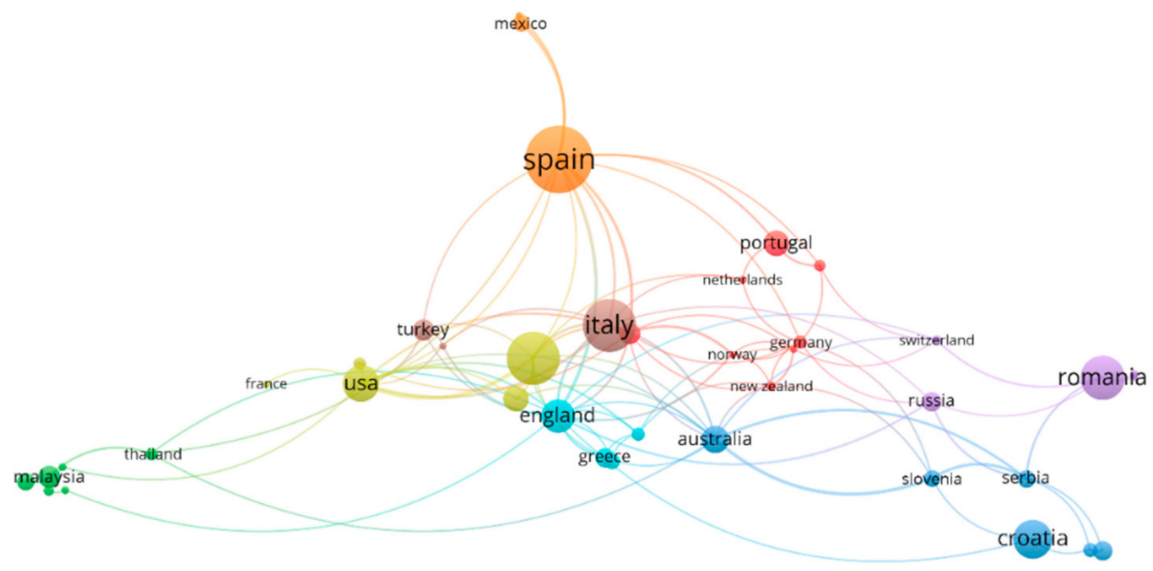

\section{B vosviewer}

Figure 17. Co-authorship network by country for TCS: 40 countries of the 86 nations in total which meet the minimum threshold of five papers for a country. 
The analysis of the relationship between countries in terms of co-authorship on TCSD provides us with a network of 24 countries divided into six clusters (Figure 18): The red cluster is composed of seven countries, with the most representative being Australia (22 publications, 215 citations), Italy (47 publications, 408 citations) and China (25 publications, 59 citations); the green cluster is composed of six countries, with the most representative being England (24 publications, 1384 citations) and Slovenia (13 publications, 359 citations); the dark blue cluster is composed of three countries, with the most representative country being Croatia (27 publications, 27 citations); the yellow cluster is composed of three countries, with the most representative country being Thailand (5 publications, 22 citations); the purple cluster is composed of three countries, where the most representative country is Spain (71 publications, 622 citations); and the light blue cluster is composed of two countries, with the most representative country being the United States (17 publications, 120 citations). Finally, it can be seen that the different clusters are fairly spaced out.

The countries that stand out in terms of the number of publications are Spain, Italy and Croatia. Conversely, if we look at the number of citations, the leading countries are England, Spain and Italy. And lastly, if we analyze total link strength, the stand-out countries are Australia, England and Spain.

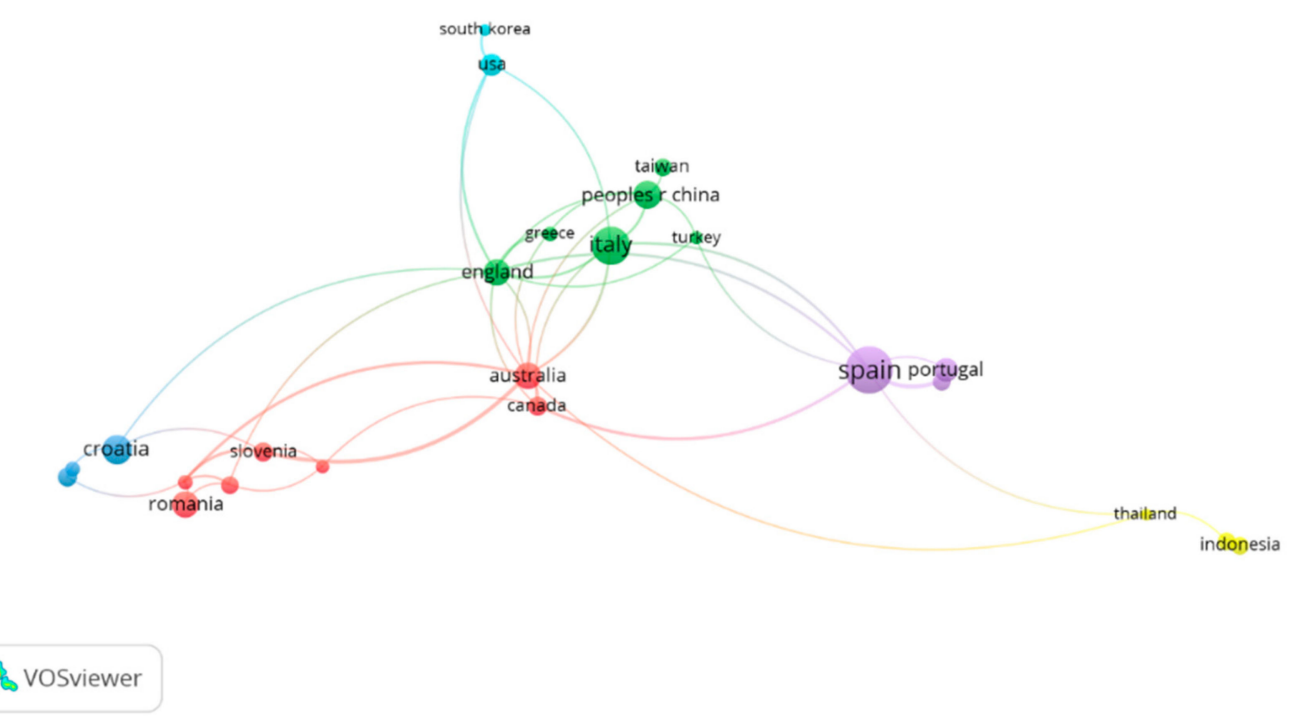

Figure 18. Co-authorship network by country for TCSD: 24 countries of the 68 nations in total which meet the minimum threshold of five papers for a country.

We then carry out the same analysis, but for organizations. In this case, of the total of 861 institutions, we can see in Figure 18 that only five of them are collaborating with each other. There are two distinct clusters: We find a clear collaboration between the University of Central Florida (with 7 publications) and the Hong Kong Polytechnic University (with 10); furthermore, in the red cluster we see the collaboration between the University of Novi Sad (7) in Serbia, the University of Ljubljana (7) in Slovenia, and Griffith University (9) in Australia.

However, although they have not collaborated with the other institutions and therefore are not reflected in the network in Figure 19, the most influential institutions in terms of number of publications are, first, the Bucharest University of Economic Studies, with 15 publications; and second, the University of Rijeka, in Croatia, with 14. 


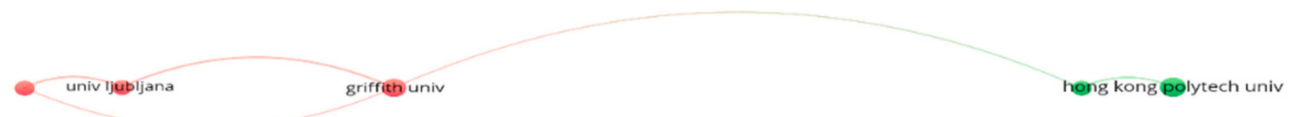

\section{Bo vosviewer}

Figure 19. Co-authorship network by institution for TCS: 26 organizations of the total of 861 which meet the minimum threshold of five publications.

Another relevant finding of the analysis of the most influential institutions is the notable presence of Spanish universities as this was the country with the most contributions (as can be seen in the analysis depicted in Figure 17). On an individual basis, these universities are not at the top of the ranking, but taken together they boost the relevance of the country. It is interesting to note that these universities have a sufficient presence to ensure that their country is the most influential, yet there is no collaboration between them. Specifically, these universities are the University of Las Palmas de Gran Canaria (10 publications), the University of Jaén (9), the University of Alicante (8), the University of the Balearic Islands (6), the University of Barcelona (6), the University of Extremadura (6), the Autonomous University of Madrid (6), and the University of Málaga (6).

Finally, when creating the co-authorship network by institution for TCSD (Figure 20), for the universities that comply with the restriction of a minimum of three publications, it can be seen that there is little collaboration between the different universities. Indeed, from the total of 457 universities, the largest group consists of only eight universities, which are organized into three clusters. The red cluster is composed of three universities: Griffith University in Australia (6 publications, 58 citations), the College of Natural Resources (CNR) in the United States (3 publications, 11 citations) and the University of Central Florida in the United States (3 publications, 15 citations). The green cluster is composed of three universities: the University of Ljubljana in Slovenia (7 publications, 276 citations), the University of New South Wales in Australia (4 publications, 19 citations) and University of Novi Sad in Serbia (5 publications, 24 citations). The blue cluster is composed of two universities: the University of Technology Sydney in Australia (3 publications, 31 citations) and the University of Canberra in Australia (3 publications, 25 citations). The importance of Australian universities can be seen as they occupy important places in the clusters; in addition, the relationship between Australian universities is notable. Furthermore, the different clusters are fairly spaced out, which means there is relatively little collaboration between them.

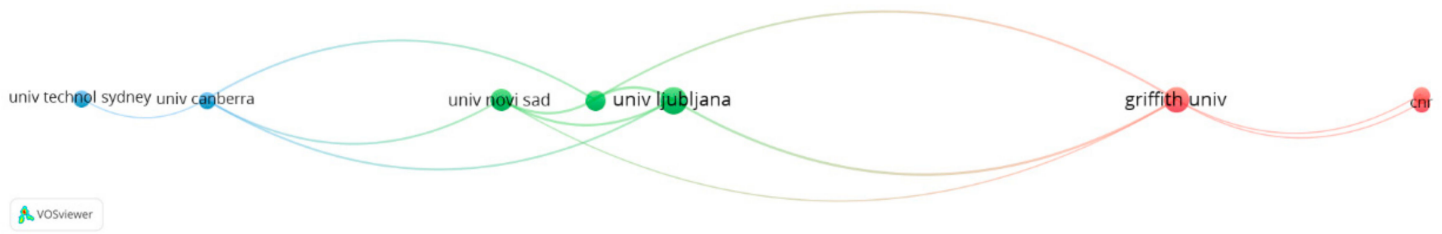

Figure 20. Co-authorship network by institution for TCSD: 8 organizations of the total of 457 which meet the minimum threshold of three publications.

\subsection{Summary}

As a summary of the above mentioned analysis, from 3.2 until 3.8, which are the main contributions we make, we present Table 6 . 
Table 6. Summary of bibliometric analysis on TCS and TCSD.

\begin{tabular}{|c|c|c|c|}
\hline Section & Objective & Result & Table/Graph \\
\hline 3.2 & $\begin{array}{l}\text { To show the number of publications by } \\
\text { year and number of citations. }\end{array}$ & $\begin{array}{l}\text { Emerging concern in TCS, mainly in 2007, although less than TC or TS. Only one article with more than } 500 \\
\text { citations, and six with more than } 100 \text { citations. } \\
\text { In TCSD, there is an important upward tendency in publications since 2007. Only one article with more than } 500 \\
\text { citations, and three with more than } 100 \text { citations. }\end{array}$ & $\begin{array}{l}\text { Figure } 6 \\
\text { Table } 1\end{array}$ \\
\hline 3.3. & $\begin{array}{l}\text { To show the most cited articles and some } \\
\text { specific characteristics. }\end{array}$ & $\begin{array}{l}\text { Tourism Management and Trends In Ecology \& Evolution gather the five most cited articles in TCS. The most cited } \\
\text { articles are Buhalis (2000) [17], Kiss (2004) [45], Mihalic (2000) [13]. } \\
\text { In TCSD, 80\% of the top } 10 \text { most cited articles were published in Tourism Management. The three most cited } \\
\text { articles on the TCSD topic are Buhalis (2000) [17], Mihalic (2000) [13] and Aguiló et al. (2005) [46]. }\end{array}$ & Table 2 \\
\hline 3.4. & $\begin{array}{l}\text { To list the journals with the highest } \\
\text { number of influential papers. }\end{array}$ & $\begin{array}{l}\text { Tourism in South East Europe, International Journal of Tourism Research and Journal of Tourism Management are } \\
\text { the highest percentage of articles published in TCS. And the main categories are: Hospitality, Leisure Sport and } \\
\text { Tourism; Environmental Studies; Management; Green and Sustainable Science and Technology; Economics; } \\
\text { Environmental Sciences; and Business. } \\
\text { The three main journals by number of publications on TCSD are: Sustainability, Tourism Management and Journal } \\
\text { of Sustainable Tourism. The main categories are: Hospitality, Leisure, Sport and Tourism; Environmental Studies; } \\
\text { Management; Green and Sustainable Science and Technology; Economics; Environmental Sciences; and Business. }\end{array}$ & Table 3 \\
\hline 3.5. & $\begin{array}{l}\text { To show the keyword co-occurrence, or } \\
\text { keywords that appear together in the same } \\
\text { article. }\end{array}$ & $\begin{array}{c}\text { The } 2.922 \text { keywords in TCS are grouped in five clusters: Tourism, Competitiveness, Sustainable tourism, } \\
\text { Management, Model. } \\
\text { In TCSD, the } 1.158 \text { keywords found are organized in six clusters: Sustainable Development, Destination, } \\
\text { Sustainable Tourism, Competitiveness, Tourism and Sustainability. }\end{array}$ & $\begin{array}{l}\text { Figures } 7 \text { and } 8 \\
\text { Tables } 4 \text { and } 5\end{array}$ \\
\hline 3.6. & $\begin{array}{l}\text { To display the existing co-citation } \\
\text { relationships between authors, papers and } \\
\text { journals. }\end{array}$ & $\begin{array}{l}\text { In TCS, the reference co-citation network analysis shows the presence of three clusters where Ritchie, J.R.B. (2003) } \\
\text { [50], Dwyer, L. (2003) [51] and Crouch, G.I. (1999) [42] represent the most cited papers in each cluster. The journal } \\
\text { co-citation network shows the presence of three clusters. These are headed up by Tourism Management, Journal of } \\
\text { Sustainable Tourism and International Journal of Hospitality Management. The author co-citation network analysis } \\
\text { shows the presence of three homogeneous clusters in terms of the number of citations and link strength of the top } \\
\text { authors. The most notable author is Dwyer, L. } \\
\text { In TCSD, the co-citation network of references shows the presence of three clusters, where Ritchie, J.R.B. (2003) [50]; } \\
\text { Dwyer, L. (2003) [51] and Liu, Z. (2003) [53] represents the most cited papers in each cluster. The journal co-citation } \\
\text { network yields six clusters where Tourism Management, Journal of Sustainable Tourism, International Journal of } \\
\text { Tourism Research, annals of Tourism Research, Journal of Destination Marketing \& Management and Tourism } \\
\text { Economics are the most cited. The author co-citation network illustrates the three clusters where Buhalis, D.; Hall, } \\
\text { C.M.; and Dwyer, L. are the most cited authors. }\end{array}$ & Figures 9-14 \\
\hline 3.7. & $\begin{array}{l}\text { To count the number of references that a } \\
\text { group of papers has in common }\end{array}$ & $\begin{array}{l}\text { In TCS, the analysis reveals a main cluster of } 15 \text { authors, followed by a second group of } 7 \text { authors. The leading } \\
\text { authors, in terms of the number of publications, are Pulido-Fernandez, J.I. and Dwyer, L. } \\
\text { In TCSD, the analysis reveals five clusters, the main one grouping seven authors. The leading authors are } \\
\text { Pulido-Fernandez, J.I. and Dwyer, L. Dwyer, L. Two clusters present emerging topics of research. }\end{array}$ & Figures 15 and 16 \\
\hline 3.8 & $\begin{array}{l}\text { To depict the networks of collaboration } \\
\text { between countries and organizations }\end{array}$ & $\begin{array}{l}\text { In TCS, at the country level, Spain leads the way in terms of number of contributions, followed by China and Italy. } \\
\text { For the institutions, the most important institutions are the Bucharest University of Economic Studies and the } \\
\text { University of Rijeka. There is a notable presence of Spanish universities. } \\
\text { In TCSD, there is a low collaboration between the six country clusters shown. About the institutions analysis, only } \\
\text { eight universities present collaboration in three clusters. There is a notable presence of Australian universities. }\end{array}$ & Figures $17-20$ \\
\hline
\end{tabular}




\section{Discussion and Conclusions}

Using bibliometric analysis of publications in WoS, this article provides an up-to-date picture of the trends in research on sustainability and competitiveness in the tourism industry, together with a specific insight into tourism destinations. The significance of this article lies in the fact that, as far we are aware, there are no previous bibliometric studies on the tourism industry that have simultaneously focused on competitiveness and sustainability. Moreover, taking an additive approach, we have incorporated the concept of tourism destination.

First, the analysis focused on the results in TS and TC. Significant growth was observed, which demonstrates the relevance of these issues. If we compare the average number of citations per article in TS and TC research, we see similar figures: In the case of TS, it is 8.32, and in the case of TC, it is 8.88. The three articles with the highest number of citations in TS research are Buhalis (2000) [3], Gössling (2002) [4] and Choi and Sirakaya (2006) [5]. On the other hand, the three articles with the highest number of citations in TC research are Buhalis (2000) [3], Crouch and Ritchie (1999) [6] Gallarza and Saura (2006) [7]. The most representative journals in TS and TC are Journal of Sustainable Tourism and Tourism Management, respectively. In both TS and TC research, China is shown to be the country with the most publications, accounting for $14.40 \%$ and $12.64 \%$ of total publications on these topics, respectively.

In light of our findings, it can be concluded that there is a rising trend in TS and TC research; however, there has been far more focus on the former than the latter in the literature, with the gap between them widening over the last decade. About 20 years ago, the gap between them amounted to about 100 articles a year, but in 2018 and the first 7 months of 2019, the gap was 1000 articles. This data may be interpreted as reflecting the increasing concern about sustainability in tourism (TS), which is growing at a far faster rate than the rising trend in research on competitiveness in the tourism industry (TC).

Thanks to the novel approach of our research, we can highlight two important differences. First, the number of publications on TCS is quite low compared to either TS or TC. This relevant finding indicates that there is still a long way to go in understanding how to implement sustainable policies that simultaneously enable competitiveness in the tourism industry. In 2018, there were 120 publications on TCS, whereas the equivalent numbers for TS and TC were 1446 and 458, respectively. Second, much more research is still needed on sustainable and competitive tourism destinations, TCSD, on which there were 63 publications in 2018. The literature on TCSD remains scarce (only 409 publications), although it has experienced growth of over 380\% in the last 10 years (2009 to 2018), outstripping the growth in the other subjects analyzed (TS: $290 \%$, TC: $278 \%$ and TCS: $300 \%$ ).

As described above, similar behaviour is observed for the number of citations in TCS and TCSD. Only one article has more than 500 citations in TCS and TCSD, while only six and three articles, respectively, got more than 100 citations. Given the importance of achieving competitive and sustainable tourism [54] —and, more specifically, competitive and sustainable tourism destinations - the numbers of publications and citations for TCS and TCSD indicate that there is still much to study, thus providing opportunities for researchers to explore this new field of research.

The top three most cited articles on TCS are Buhalis (2000) [3], Kiss (2004) [45] and Mihalic (2000) [9], with 49.70, 15.56 and 12.15 citations per year respectively.

The top three most cited articles on TCSD are Buhalis (2000) [3], Mihalic (2000) [9] and Aguiló et al. (2005) [10]. It is important to note that Buhalis (2000) [3], with a total of 994 citations, appears as the most cited article in the four searches carried out (TS, TC, TCS, TCSD), because it defines the concept of destination and examines the effect of destination marketing on the competitiveness of destinations.

The top journals in terms of the number of articles published on TCS and TCSD are Sustainability, Tourism Management and Journal of Sustainable Tourism. TCSD research represents only a small percentage of the total research presented in the top 10 journals (with coverage ranging from $0.02 \%$ to $1.45 \%)$. 
The most frequent keywords reveal the main topics in a specific area of research. For TCS, our analysis emphasizes the keywords "tourism", "competitiveness", "sustainable tourism", "management", and "model". These keywords reflect the main trends followed by researchers. They indicate that the concept of a competitive and sustainable tourism industry goes, or should go, hand in hand with appropriate management systems, processes and models that enable and help to achieve the desired competitiveness and sustainability.

The most notable keywords for TCSD are "tourism", "sustainability", "competitiveness", "sustainable development", and "sustainable tourism". In addition, the co-occurrence network of author keywords features "Innovation", "Cooperation", "Strategy", and "Stakeholders". These keywords are related to the concepts of tourism clusters and tourism destination.

For TCS, the reference co-citation network analysis shows the presence of a dominant cluster, containing the leading articles in this analysis Ritchie, J.R.B. (2003) [50] with 78 citations, Dwyer, L. (2003) [51] with 73 citations and Crouch, G.I. (1999) [42] with 71 citations. The second cluster, and especially the third cluster, are a long way off in relation to the number of citations.

The analysis of the co-citation of references on TCSD shows three clusters, with the most important references found in the first two clusters: Ritchie, J.R.B. (2003) [50] with 72 citations, Dwyer, L. (2003) [51] with 68 citations, and Crouch G.I. (1999) [42] with 66 citations. The third cluster, in which the most important reference is Liu (2003) [53] with 23 citations is farther away in relation to the number of citations and also shows a lesser relationship with the other two clusters.

As for the analysis of the journal co-citation network for TCS, there are three main clusters. The first is headed up by Tourism Management, the second by Journal of Sustainable Tourism, and the third by International Journal of Hospitality Management. The topics of these journals are tourism and travel, sustainability, and management, respectively.

At the TCSD level, six clusters can be observed. The first is headed up by Tourism Management, the second by Journal of Sustainable Tourism, the third by International Journal of Tourism Research, the fourth by Annals of Tourism Research, the fifth by Journal of Destination Marketing \& Management, and the sixth by Tourism Economics. These journals are mainly focused on the categories of Hospitality, Leisure, Sport and Tourism, and Environmental Studies.

In the author co-citation network analysis for TCS, we find three fairly homogeneous clusters in terms of the number of citations and link strength of the top authors. Nevertheless, the most notable author in relation to these two aspects is Dwyer, L. (202 and 1544).

In the case of TCSD, there are three clusters, in which the most important authors in terms of level of citations and link strength are Dwyer, L. (187 and 1512), Hall, C.M. (132 and 1623) and Buhalis, D. (143 and 1134).

In terms of the number of authors belonging to the same cluster, the bibliographic coupling of authors in TCS reveals a main cluster of 15 authors, followed by a second group of 7 authors. As for the leading author in terms of the number of publications, we have Pulido-Fernandez, J.I. with seven, who belongs to the largest cluster. In second position is Dwyer, L. with five publications, but assigned to one the smallest clusters, in which only four authors are grouped.

For TCSD, the bibliographic coupling of authors reveals five clusters. There is a main cluster of seven authors, followed by the second most important cluster of four authors. The leading authors are Pulido-Fernandez, J.I. with seven publications; Dwyer, L. with five; and Buffa, F. with four. Two of the clusters, which are farther away from the other three, present emerging topics of research. One is made up of Kruger, M. and Saayman, M., and the other of Dwyer, L., Armenski, T. and Mihalic, T.

Regarding the analysis of co-authorship relationships between countries and institutions for TCS, we find that, at the country level, Spain leads the way in terms of number of contributions, followed by China and Italy. As for the institutions, we observe the interesting fact that although the Spanish universities are responsible for the most contributions (at country level rather than individually), they do not engage in any kind of collaboration with each other. The most important institutions are the 
Bucharest University of Economic Studies and the University of Rijeka. The most notable collaboration is between the University of Central Florida and the Hong Kong Polytechnic University.

Regarding the analysis of co-authorship relationships between countries for TCSD, there are six clusters, headed up by Australia, England, Croatia, Thailand, Spain, and the United States. It can be seen that the different clusters are relatively far apart from each other, indicating a less collaborative relationship. Finally, the analysis of the co-authorship network of institutions for TCSD shows only eight universities organized into three clusters, headed up by Griffith University in Australia, the University of Ljubljana in Slovenia and the University of Technology Sydney in Australia. Particularly notable is the role played by Australian universities both in collaboration with universities from other countries and among national universities.

Given the results of our bibliometric analysis, our study sheds light on the main research topics in the literature on TCS and TCSD, and, consequently, on potential trends. Our study can help researchers by highlighting different concepts and the links between them, thereby suggesting future lines of research. In this vein, our article reveals a number of clear trends. The first is the increasing importance of TS, as shown by the number of publications in WoS [19]. The second is the rise in the number of articles published related to TC. Third, the gap between TS and TC reveals a need for greater insight into how to improve competitiveness in this sector. Fourth, we found a substantial gap separating TCS from TC and TS, indicating that the coexistence of these two attributes in the tourism industry requires more in-depth knowledge, thus calling for greater attention from researchers [55]. It can be explained by the lack of interaction between the academic world and the tourism industry $[14,56]$. Fifth, in the case of TCSD, there has been an increase in the number of published articles, although the growth has been less explosive than in TS and TC. Furthermore, there is a gap between TCS and TCSD in terms of the amount of research, pointing to the need for further research on the management, governance and marketing of tourism destinations and their impact on the competitiveness and sustainable development of the destination $[13,46]$. Sixth, the keyword analysis also highlights a need to include new fields of knowledge in TS, TC, TCS, and TCSD [17,24,29]. Environmental concerns and related issues must be addressed in connection with strategy and management, thereby enabling the enduring success of companies and organizations in a sustainable manner. Seventh, regarding the research on TCDS, it is also worth highlighting the need for joint work between different universities (from different countries), as there has been little such collaboration to date. This collaboration will enable the exchange of knowledge and best practices of tourism destinations.

Our study is also helpful for practitioners. Business organizations should take into account the findings from the research literature. The complexity of achieving TSC and TSCD requires an innovative approach in which the transformation comes from a global perspective incorporating other disciplines [55]. In that vein, sustainability must go hand in hand with the management approach, marketing strategies, social issues, and technology, etc. Since stakeholders sometimes seem to view sustainable tourism as providing no kind of competitive advantage [16], the literature also helps practitioners to recognize the benefits of being sustainable. In addition, as governments play an active role in encouraging responsible behaviour [16], tackling the abovementioned complexity requires policies, incentives and regulations to encourage and motivate the private sector [57]. Regarding TCSD research, it highlights the importance of cooperation and creation of networks between the public and private sector, in order to boost the competitiveness of tourism. This may lead to further research collaborations between universities, tourism businesses and governments, creating networks within a region or country that enables the generation of knowledge and technological development, as well as their application.

Nevertheless, when it comes to limitations, our study is no exception. First, our findings could be extended by using other well-known databases such as Scopus [58]. Secondly, the use of keywords might be puzzling. Third, we do not consider other sources of information, such as articles in languages other than English. 
Author Contributions: Conceptualization, L.S.-A. and J.A.C.-A.; Data curation, R.M. and M.G.G.; Formal analysis, R.M. and M.G.G.; Investigation, R.M. and M.G.G.; Methodology, L.S.-A., J.A.C.-A., R.M. and M.G.G.; Project administration, L.S.-A. and J.A.C.-A.; Resources, J.A.C.-A., R.M. and M.G.G.; Software, R.M. and M.G.G.; Supervision, L.S.-A. and J.A.C.-A.; Validation, L.S.-A., J.A.C.-A., R.M. and M.G.G.; Visualization, R.M. and M.G.G.; Writing-original draft, L.S.-A., J.A.C.-A., R.M. and M.G.G.; Writing—review \& editing, L.S.-A., J.A.C.-A., R.M. and M.G.G.

Funding: This research was funded by the Ministry of Science, Innovation and Universities grant number [FPU17/04804].

Conflicts of Interest: The authors declare no conflict of interest.

\section{References}

1. Andrew, W.P.; Damitio, J.W.; Schmidgall, R.S. Financial Management for the Hospitality Industry, 2nd ed.; Pearson Prentice Hall: Upper Saddle River, NJ, USA, 2007.

2. Singal, M. How is the hospitality and tourism industry different? An empirical test of some structural characteristics. Int. J. Hosp. Manag. 2015, 47, 116-119. [CrossRef]

3. Mariz-Pérez, R.; García-Álvarez, T. The internationalization strategy of spanish indigenous franchised chains: A resource-based view. J. Small Bus. Manag. 2009, 47, 514-530. [CrossRef]

4. Hernández-Maestro, R.M.; Muñoz-Gallego, P.A.; Santos-Requejo, L. Small-business owners' knowledge and rural tourism establishment performance in Spain. J. Travel Res. 2009, 48, 58-77. [CrossRef]

5. Lee, J.W.; Brahmasrene, T. Investigating the influence of tourism on economic growth and carbon emissions: Evidence from panel analysis of the European Union. Tour. Manag. 2013, 38, 69-76. [CrossRef]

6. Su, Y.W.; Lin, H.L. Analysis of international tourist arrivals worldwide: The role of world heritage sites. Tour. Manag. 2014, 40, 46-58. [CrossRef]

7. Camisón, C.; Forés, B.; Puig-Denia, A. Return on capital in Spanish tourism businesses: A comparative analysis of family vs non-family businesses. Eur. J. Manag. Bus. Econ. 2016, 25, 91-110. [CrossRef]

8. Getz, D.; Carlsen, J. Family business in tourism. State of the art. Ann. Tour. Res. 2005, 32, 237-258. [CrossRef]

9. Camisón, C. La competitividad de la empresa familiar y sus factores determinantes: Un modelo explicativo. In Cátedra de Empresa Familiar; Universitat de Valencia: Valencia, Spain, 2014.

10. Saarinen, J. Traditions of sustainability in tourism studies. Ann. Tour. Res. 2006, 33, 1121-1140. [CrossRef]

11. Chancellor, C.; Norman, W.; Farmer, J.; Coe, E. Tourism organizations and land trusts: A sustainable approach to natural resource conservation? J. Sustain. Tour. 2011, 19, 863-875. [CrossRef]

12. Stabler, M.J.; Goodall, B. Environmental awareness, action and performance in the Guernsey hospitality sector. Tour. Manag. 1997, 18, 19-33. [CrossRef]

13. Mihalič, T. Environmental management of a tourist destination: A factor of tourism competitiveness. Tour. Manag. 2000, 21, 65-78. [CrossRef]

14. Buckley, R. Sustainable tourism: Research and reality. Ann. Tour. Res. 2012, 39, 528-546. [CrossRef]

15. Bramwell, B. Governance, the state and sustainable tourism: A political economy approach. J. Sustain. Tour. 2011, 19, 459-477. [CrossRef]

16. Camilleri, M.A. Responsible tourism that creates shared value among stakeholders. Tour. Plan. Dev. 2016, 13, 219-235. [CrossRef]

17. Buhalis, D. Marketing the competitive destination of the future. Tour. Manag. 2000, 21, 97-116. [CrossRef]

18. Alén, E.; Domínguez, T.; Losada, N. New opportunities for the tourism market: Senior tourism and accessible tourism. In Visions for Global Tourism Industry: Creating and Sustaining Competitive Strategies; BoD Books on Demand: Norderstedt, Germany, 2012.

19. Yoopetch, C.; Nimsai, S. Science mapping the knowledge base on sustainable tourism development, 1990-2018. Sustainability 2019, 11, 3631. [CrossRef]

20. Garau, C. Emerging technologies and cultural tourism: Opportunities for a cultural urban tourism research agenda. In Tourism in the City: Towards an Integrative Agenda on Urban Tourism; Springer: Cham, Switzerland, 2016; pp. 67-80.

21. Jelinčić, D.A.; Mansfeld, Y. Applying cultural tourism in the revitalisation and enhancement of cultural heritage: An integrative approach. In Cultural Urban. Heritage; Springer: Cham, Switzerland, 2019; pp. 57-64.

22. Johnston, P.; Everard, M.; Santillo, D.; Robèrt, K.H. Reclaiming the definition of sustainability. Environ. Sci. Pollut. Res. 2007, 14, 60-66. 
23. Torres-Delgado, A.; Saarinen, J. Using indicators to assess sustainable tourism development: A review. Tour. Geogr. 2014, 16, 31-47. [CrossRef]

24. Garrigos-Simon, F.J.; Narangajavana-Kaosiri, Y.; Narangajavana, Y. Quality in tourism literature: A bibliometric review. Sustainability 2019, 11, 3859. [CrossRef]

25. Coltman, M.M. Tourism Marketing; Van Nostrand Reinhold: New York, NY, USA, 1989.

26. Ferri Sanz, M.; Durá Ferrandis, E.; Garcés Ferrer, J. Service quality scales and tourists with special needs: A systematic review. Sustainability 2019, 11, 3844. [CrossRef]

27. Kim, H.; Joun, H.J.; Choe, Y.; Schroeder, A. How can a destination better manage its offering to visitors? Observing visitor experiences via online reviews. Sustainability 2019, 11, 4660. [CrossRef]

28. Li, N.; Han, R.; Lu, X. Bibliometric analysis of research trends on solid waste reuse and recycling during 1992-2016. Resour. Conserv. Recycl. 2018, 130, 109-117. [CrossRef]

29. Garrigos-Simon, F.J.; Narangajavana-Kaosiri, Y.; Lengua-Lengua, I. Tourism and sustainability: A bibliometric and visualization analysis. Sustainability 2018, 10, 1976. [CrossRef]

30. Merigo, J.M.; Blanco-Mesa, F.; Gil-Lafuente, A.M.; Yager, R.R. A bibliometric analysis of the first thirty years of the International Journal of Intelligent Systems. In Proceedings of the 2016 IEEE Symposium Series on Computational Intelligence (SSCI), Athens, Greece, 6-9 December 2016.

31. Garfield, E. KeyWords plus-ISI's breakthrough retrieval method. 1. Expanding your searching power on current-contents on diskette. Curr. Contents 1990, 1, 5-9.

32. Ji, L.; Liu, C.; Huang, L.; Huang, G. The evolution of resources conservation and recycling over the past 30 years: A bibliometric overview. Resour. Conserv. Recycl. 2018, 134, 34-43. [CrossRef]

33. UNWTO. UNWTO Tourism Definitions; World Tourism Organization: Madrid, Spain, 2019; p. 58.

34. Merigó, J.M.; Rocafort, A.; Aznar-Alarcón, J.P. Bibliometric overview of business \& economics research. J. Bus. Econ. Manag. 2016, 17, 397-413.

35. Merigó, J.M.; Yang, J.B. Accounting research: A bibliometric analysis. Aust. Account. Rev. 2017, $27,71-100$. [CrossRef]

36. Van Eck, N.J.; Waltman, L. VOSviewer: A computer program for bibliometric mapping. In Proceedings of the 12th International Conference on Scientometrics and Informetrics, Rio de Janeiro, Brasil, 28-31 July 2009; pp. 886-897.

37. Wang, Y.; Lai, N.; Zuo, J.; Chen, G.; Du, H. Characteristics and trends of research on waste-to-energy incineration: A bibliometric analysis, 1999-2015. Renew. Sustain. Energy Rev. 2018, 66, 95-104. [CrossRef]

38. Child, T.G.F.; Heath, R.A. Underselling national parks in Zimbabwe: The implications for rural sustainability. Soc. Nat. Resour. 1990, 3, 215-227. [CrossRef]

39. Wall, G. Human Ecology, Tourism and Sustainable Development. Ann. Tour. Res. 1990, 17, $633-635$. [CrossRef]

40. Gössling, S. Global environmental consequences of tourism. Glob. Environ. Chang. 2002, 12, $283-302$. [CrossRef]

41. Choi, C.H.S.; Sirakaya, E. Sustainability indicators for managing community tourism. Tour. Manag. 2006, 27, 1274-1289. [CrossRef]

42. Crouch, G.I.; Ritchie, B.J.R. Tourism, competitiveness, and societal prosperity. J. Bus. Res. 1999, 44, $137-152$. [CrossRef]

43. Gallarza, M.G.; Saura, I.G. Value dimensions, perceived value, satisfaction and loyalty: An investigation of university students' travel behaviour. Tour. Manag. 2006, 27, 437-452. [CrossRef]

44. Poon, A. The 'new tourism' revolution. Tour. Manag. 1994, 15, 91-92. [CrossRef]

45. Kiss, A. Is community-based ecotourism a good use of biodiversity conservation funds? Trends Ecol. Evol. 2004, 19, 232-237. [CrossRef] [PubMed]

46. Aguiló, E.; Alegre, J.; Sard, M. The persistence of the sun and sand tourism model. Tour. Manag. 2005, 26, 219-231. [CrossRef]

47. Hirsch, J.E. An index to quantify an individual's scientific research output. Proc. Natl. Acad. Sci. USA 2005, 102, 16569-16572. [CrossRef] [PubMed]

48. Van Eck, N.J.; Waltman, L. VOSviewer Manual 1.6.11; Univeristeit Leiden: Leiden, The Netherlands, 2019.

49. Small, H. Co-citation in the scientific literature: A new measure of the relationship between two documents. J. Am. Soc. Inf. Sci. 1973, 24, 265-269. [CrossRef] 
50. Ritchie, J.; Crouch, G. The Competitive Destination: A Sustainable Tourism Perspective; CABI Publishing: New York, NY, USA, 2003.

51. Dwyer, L.; Kim, C. Destination competitiveness: Determinants and indicators. Curr. Issues Tour. 2003, 6, 369-414. [CrossRef]

52. Barney, J. Firm resources and sustained competitive advantage. J. Manag. 1991, 17, 99-120. [CrossRef]

53. Liu, Z. Sustainable tourism development: A critique. J. Sustain. Tour. 2003, 11, 459-475. [CrossRef]

54. European Commission. Reserch EU Focus; Publications Office: Luxembourg, 2008; Volume 1, p. 32.

55. Budeanu, A.; Miller, G.; Moscardo, G.; Ooi, C.S. Sustainable tourism, progress, challenges and opportunities: An introduction. J. Clean. Prod. 2016, 111, 285-294. [CrossRef]

56. Lane, B. Thirty years of sustainable tourism. Drivers, progress, problems-And the future. In Sustainable Tourism Futures. Perspective on Systems, Restructuring and Innovations, 1st ed.; 209AD; Gössling, S., Hall, C.M., Weaver, D.B., Eds.; Routledge: New York, NY, USA, 2009; pp. 19-32.

57. Booyens, I. Rethinking township tourism: Towards responsible tourism development in South African townships. Dev. South. Afr. 2010, 27, 273-287. [CrossRef]

58. Niñerola, A.; Sánchez-Rebull, M.V.; Hernández-Lara, A.B. Tourism research on sustainability: A bibliometric analysis. Sustainability 2019, 11, 1377. [CrossRef]

(C) 2019 by the authors. Licensee MDPI, Basel, Switzerland. This article is an open access article distributed under the terms and conditions of the Creative Commons Attribution (CC BY) license (http://creativecommons.org/licenses/by/4.0/). 